\title{
4 \\ Surveying the Cow Care Field
}

In this chapter, I look at current cow care practices in India. By "cow care" I mean, minimally, intentional arrangements for bovines to be protected for the duration of their natural lives. My primary aim is to provide an overview of issues that concern persons - in particular persons who identify more or less as Hindus - who are directly or indirectly engaged with cow care. Of course, the issues are centrally about the protection and wellbeing of the cows these persons are involved in caring for. Specifically, we want to consider what are the essential components of Hindu cow care. What makes this practice different, or similar, to any practice of cattle husbandry such as agribusiness dairy farming or ranching? What are the special challenges and constraints of Hindu cow care, and what are its rewards? Pursuing these questions, we will look at some specific cow care projects in India, and we will listen to some of the persons involved in these. It would be presumptuous to claim these vignettes to be fully representative of thought and practices in the wide scope of present-day Hindu cow care. Still, they show an important cross-section of mainly Vaishnava Hindu practice, especially in northern and western India. 
The story this chapter tells is one of largely provisional measures to care for a relatively infinitesimal number of bovines in comparison with the number of those that become victim to the massive Indian dairy industry and therefore the meat and leather industries. It is a story of attempts, however small, to address India's increasingly festering condition of burgeoning cities and of human alienation from nature, a major symptom of which is seen in the pervasiveness of stray cows. This is the visible side of a dark reality_ - of dairy, meat, leather, and related industries' largely invisible operations that are legal, quasi-legal, or illegal but tolerated.

In contexts of cow care practices, what we will see are conscientious and sometimes self-conscious efforts to bring ideals to bear within the persistent realities of economic and related uncertainties. The broader reality, however, is a general public apathetic neglect of cows fueled by changing human diets attenuating a residual reverence for cows-a reverence that from time to time becomes sharply ignited in the political sphere.

One is inclined to point, above all, to ahimsa-nonviolence, as the most essential, emblematic ideal, from which other ideals of cow care follow. No doubt ahimsa is a central principle for cow care ethics and practice. And it is this ideal that brings the greatest challenge, for as understood by my informants, the irreducible requirement called for in go-seva and go-raksha (cow care and cow protection) is seeing to it that cows and bulls are maintained for their entire natural lives, whatever may be their "utility" or apparent liability. To what extent and how the attempt to uphold this ideal for cows-especially deshi (Indian indigenous) cowsmay involve indirect or unintended violence in other spheres, or indeed, whether and to what extent the cow care practices described here can be regarded as truly nonviolent, will be questions to be kept in mind here and to be addressed more explicitly in Chapter 5. Here our main concern is with what are currently some practical means used in pursuit of the ahimsa ideal as lifelong cow care, and what further cultural resourceswhether explicitly Hindu or otherwise (including modern organizational and technical resources) - are drawn upon to make contemporary cow care sustainably functionable and expandable. 


\section{Cows (Un)Sheltered}

In 1970, the National Dairy Development Board of India launched a major project to increase dairy production, known as Operation Flood. The project involved initial financing from Europe to create Indian national milk processing facilities and transport infrastructure. The core principle of the project was empowerment of individual small farmers and dairy keepers, connecting them to large production and distribution facilities through a network of dairy cooperatives. Operation Flood (also known as the "White Revolution") proved to be an impressive success, such that before the year 2000 India's annual dairy production equaled or surpassed that of the United States (Scholten 2010, p. 1). Providing 18 million people (70\% women) with employment, dairy became a major source of income for more than 27 million people (World Animal Protection 2014). ${ }^{1}$

What has been good for the Indian dairy industry and the Indian economy in general has not been good for either the dairy cows or their offspring. As with any Western dairy operation, aside from the several types of abuse imposed on cows to increase their milk yield — among them artificial insemination (especially in crossbreeding with Western cow breeds), hormonal manipulation, excessive confinement, and removal of calves from their mothers - is the shortened lifespan and destiny for slaughter of both male and female bovines.

For dairy farmers (who are Hindus in most areas), economic pressures to maintain their business give them generally three options what to do with a cow that no longer brings income. She can be set loose, leaving her to wander freely and forage as best she can; give her to a goshala or pinjrapole (a cow shelter or a Jain animal shelter) possibly paying for her care; or sell her to a dealer, who supplies cattle to slaughterhouses (Nagy 2019, p. 254;

\footnotetext{
1The award-winning 1976 Hindi film Manthan (The Churning; directed by Shyam Benegal, who wrote the story together with Verghese Kurien, Operation Flood's mastermind) portrays the beginnings of Operation Flood in Gujarat, focusing on village-level politics and the cultural inertia resisting state-sponsored cooperative dairy development. While representing well the struggle of Indian small dairy farmers (indeed, the film was, perhaps uniquely, funded by the 2-rupee contributions of 500,000 dairy farmers of Gujarat), no attention is given to the cooperative development's implications for the cows providing the milk.
} 
Kennedy et al. 2018). ${ }^{2}$ In the early years after Indian Independence, prior to the launch of Operation Flood, the Indian Government set up cattle sanctuaries called gosadans, where "old, infirm, or otherwise useless" cows would be cared for. However, these proved to be financially unviable, and the scheme was abandoned (Nagy 2019, p. 254). ${ }^{3}$

Conscientious Hindu farmers, not wanting to be instrumental in cow slaughter, may be inclined to set loose their unprofitable cows, a practice that follows a tradition called anna-pratha, literally "food practice" (Jha 2017). Presumably, this was based on earlier existence of extensive public grazing lands, separated from farmlands. ${ }^{4}$ But today, such grazing lands have shrunk radically or are non-existent; instead, many cows seek their fortune in the city, where they are more likely to meet with dire misfortune.

Some activists, such as Devi Chitralekha, work intensely to promote awareness of this increasing problem. Devi Chitralekha is a young, popular Bhagavata kathakar (public reciter of the Bhagavata Purana) in the Delhi area. During one recitation to a sizeable crowd (plus a television audience), while speaking of Krishna's cowherd activities as described in the Bhagavata text, Devi paused her narration to deliver an impassioned admonishment to her listeners. Knowing that many — perhaps most—of her listeners have lapsed from the strict vegetarian dietary standard that would be expected

\footnotetext{
${ }^{2}$ Kennedy et al. suggest that farmers' fear of backlash from activists is as much a motivation for not slaughtering or selling for slaughter as is farmers' veneration for cows. See also Baviskar (2016, pp. 395-407) on dairies in Delhi and the complexities of conflicting interests with "bourgeois environmentalists" to remove Delhi's 35,000 wandering dairy cows-and hence the dairies-from the city's streets).

${ }^{3}$ Nagy (2019, p. 254), citing F. Simoons (1980), writes, "One study reported that it cost up to three times more per animal at a gosadan than it cost per person for education. The failed state-sponsored gosadan scheme influenced the Supreme Court to favor cow protection laws that 'allowed for the slaughter of useless cattle and allowed for the protection of useful ones'." The economically viable gosadan practice hinged on the hope that collected dung for fertilizer and leather from naturally dying cattle would cover their maintenance costs. Whether the experiment was bound to fail or whether mismanagement was involved may not be known.

${ }^{4}$ In his tract Gaukarunānidhi (referred to in the previous chapter), Swami Dayananda Saraswati notes that in earlier, pre-Muslim times, kings would keep half of their land for animal grazing. The current amount of grazing land in India is estimated to be $4 \%$ (Chakravarti 1985, p. 33). See also Roy (2017, p. 167). Gadgil and Guha (1995, pp. 91-93) discuss a specific instance of the grazing land issue with respect to ongoing conflicts between the "omnivores" (modern, non-tribal Indians) and "ecosystem people" (tribals), whereby denial of cattle grazing land by the former (state sanctioned) in the National Park at Bharatpur (Rajasthan) has had devastating results to the local ecology.
} 
for many Hindu castes, she urged them not to succumb to the social pressures of modern city life. ${ }^{5}$ Connecting dietary choice with the fact that India currently has thousands of slaughterhouses (some legal and five times as many illegal), ${ }^{6}$ she then appealed to them to consider the plight of the cows that are still alive but are seen wandering the streets in her listeners' neighborhoods. ${ }^{7}$ She exhorted her audience:

Please hear me out ... Whatever garbage you collect in your homes and then throw in the bin, please don't wrap anything edible ... in any kind of plastic or polyethylene and throw it away ... Cows are attracted by the smell of food and consume the whole polyethylene together with the food and the garbage. And plastic in the stomach is such a frightening illness for the cows, which cannot be treated by any medicine but can only be removed by operation. ${ }^{8}$

\section{A homeless cow that has become particularly bloated as a result of ingesting plastic may be noticed by a local resident who might-if conscientious}

\footnotetext{
5101 See Biswas (2018), "The myth of the Indian vegetarian nation." For detailed discussions of Indian food semiotics, see several articles in Khare (1992).

${ }^{6}$ Maneka Gandhi insists that all slaughterhouses in India are illegal, because the so-called legal slaughterhouses slaughter many more times the number of animals they are officially permitted to slaughter (personal communication, 5 February 2019).

${ }^{7}$ Kelsi Nagy, who researched urban cattle practices in Mysore from 2015, writing to me (23 May 2018), notes that many urban cows have owners who let them out to wander in the morning and to whom they return, of themselves, in the evening. "In Mysore, almost all of the street cattle will be owned by an urban dairy farmer and a handful were kept as pets. Most farmers I spoke to told me that when their cows reached the end of their production cycle that they were either taken to a cattle fair where they were sold to a middleman (with the unspoken understanding that the middleman then sold them to the butcher) or they 'gave' or sold them to 'the Muslims' which also meant they would be butchered. A handful told me they gave their cattle to the Gaushala [goshala], although the director of Mysore's largest Gaushala told me this almost never happened and nearly all of the cattle they had in their Gaushala had been brought by the police that intercepted a truck taking cattle to Kerala for slaughter or were male calves that had been abandoned, often without even receiving their mother's first milk and these calves nearly always died. In Mysore urban dairy cattle were kept in a shed or tied up at night to protect from theft. I was told Muslims were stealing cattle at night and would also take strays."

${ }^{8}$ https://www.youtube.com/watch?v=nRdzQhoDmWQ (Translation from Hindi, accessed 21 May 2018).
} 
and knowing of a nearby cow shelter (goshala)— phone the goshala and have the cow taken there for treatment. ${ }^{\text {? }}$

One shelter that accepts and treats such cows is Kamdhenu Dham Gaushala in Carterpuri, on the outskirts of Gurugram (Gurgaon), a one-million population satellite of Delhi. This goshala's manager, retired Brigadier S. S. Chohan, confirms Devi Chitralekha's account, adding that, along with forty to fifty kilograms of plastic,

Every cow in Gurgaon has eaten ... dirty material like nails, glass, detergent powder packets, blades, clips, even baby shoes. So, whatever we throw in the garbage in bags, she swallows it. She cannot open it, so she swallows it. And it is non-biodegradable. It ends up poisoning her and she dies. ${ }^{10}$

Kamdhenu Dham Gaushala has three veterinary doctors who live at the facility, taking in and treating cows that may be brought by the shelter's cow ambulance any time of day or night. A cow seen to have such foreign matter in her gut will be operated, after which, if all goes well, she can, in this particular goshala, expect to live out her life well attended by a trained and dedicated staff.

Chohan explains that the shelter's 3000 cows and bulls receive a more generous and richer diet than cows in most goshalas are likely to receive. Following the advice of a nutritionist, here the cows receive three meals per day, including some 15-20 kilograms of green fodder (per cow), 3-4 kilograms of a seven-grains mixture, 50 grams of rock salt (to increase the appetite), 30 grams of mineral mixture, and during the winter, 100-150 grams of jaggery (non-centrifugal cane sugar). Chohan's reasoning for giving such a good-and expensive ${ }^{11}$ — diet to the cows is twofold. One is his concern that his goshala keeps its status as a model goshala for India, and second,

\footnotetext{
${ }^{9}$ Doron and Jeffrey (2018, pp. 43-44) note that plastic came to India in the 1970s, and the combination of a burgeoning middle-class and a population density of 445 persons per square kilometer, refuse processing, has become a major issue. This, despite a vast difference in the amount of waste produced by, for example, Americans, who create 150 times more waste than the average Indian. ${ }^{10}$ Interview with Brig. S. S. Chohan, 13 February 2018. See Doron and Jeffrey (2018, Chapter 2) on the waste problem in present-day India, a direct consequence of exploding economic growth. ${ }^{11}$ The current average cost of maintaining one cow at Kamdhenu Dham Gaushala is 80 rupees per day, or 2400 rupees (ca. \$35) per month.
} 
Because these are not ordinary cows. They have endured cruelties every day. Some of them, a loaded truck passes over them in the night, so you can imagine, their backbone and all their bones are crushed. They are disoriented ... traumatized; and they cannot even stand, they are so weak [when they first arrive at the goshala].

Having been traumatized, rescued cows loathe to be approached by humans. Chohan explains that when newly arrived cows are brought to the goshala facility, he wants to approach them. However,

They seem to tell me, "Don't come near us!" I get this message from them: "You humans have tortured us, you are our greatest enemy; because of you we are on the roads; as long as we give milk, we are treated as 'divine mothers'-go-mata - and after we stop giving milk, you send us theregarbage dumps—-for dying!?”

Thus, Chohan shows a sense of being able to hear these cows, ${ }^{12}$ and the cows are, with his help, given voice, with which they express their sense of betrayal by humans. People's reverence for cows as "divine mothers" is, he suggests, a "conditional divinity" dependent on the flow of milk. Once a cow has passed her milk-giving age, the reverence may linger but the care will fade and then drop away.

As noted, Brigadier Chohan strives to maintain high standards of care in his goshala, which has been officially recognized as a model goshala by the Animal Welfare Board of India. ${ }^{13}$ After describing the plight of the

\footnotetext{
${ }^{12}$ Chohan remarked, "First you must understand the cows' language, then they will understand your language."

${ }^{13}$ Chohan has produced a standard operating procedures document for goshalas, consisting of forty points. These include specifications of space required for the cow shed $(120 \times 40$ feet, for 150 cows), size and height of feeding mangers, the need for proper ventilation and availability of sunlight, fans and heaters ("The cattle should feel comfortable and at ease at all times during all seasons in the cow sheds"), and space outside the shed for roaming, basking, and ruminating; a properly equipped hospital ("the nerve center of the goshala") with qualified, dedicated, resident veterinary staff, who perform regular vaccination and deworming as well as necessary treatments for sick and injured cows, including surgery; exacting details on feed standards, importance of proper inspection and storage of fodder, and importance of clean drinking water; the importance of daily cleaning and antibacterial spraying ("the cows are very fond of cleanliness"); the necessity of daily record-keeping of all aspects of the goshala and the cows' treatment; and cow dung management. His final stipulation is, "The Gaushala should be a place where people can experience peace and happiness in a serene
} 
rescued cows and the special attention he and his eighty assistants give them, Chohan reports that after three months of such care, "the cows are laughing, healthy." Now the cows become approachable and, we are told, positively responsive to the show of human affection. ${ }^{14}$

It is late afternoon, the regular time when the cows at Kamdhenu Dham Gaushala have just returned to the metal-roofed open stall from their roofless corrals. Several local people, including children, are circumambulating the cow pens in clockwise direction - a way considered to both honor cows and to receive general physical and mental well-being from cows' proximity. In the stalls, the cows, although not tied up, are nonetheless quite crowded together. Chohan worries, because the goshala's capacity has already been overreached, and there are still many roaming cows in the Gurugram area needing shelter. ${ }^{15}$

To ease the pressure of increasing numbers, in previous years this goshala experimented with selling rehabilitated cows to carefully selected recipients-farmers who had to first show qualification according to written standards. ${ }^{16}$ Most importantly, cows were not to be either further sold, given away, or let loose, but were to be maintained throughout their natural lives. But, Chohan says with disappointment, he decided to stop this practice because, despite promises and signed affidavits, some of the farmers, after a time, would again abandon the cow or bull they had previously

environment created by clean and green surroundings with soft and soothing devotional music filling the air."

${ }^{14}$ In a later interview, Chohan commented, "If you love the cows with intensity, the cows will love you with twice the intensity!".

${ }^{15}$ There is a similar situation of overcrowding in government goshalas in Delhi. The Times of India (Gandhiok 2019, 16 January 2019) reported, "The Shree Krishna Gaushala, located in Sultanpur Dabas, Bawana, is Delhi's biggest [goshala] and spread over 36 acres. It can accommodate up to 7740 cows. On some occasions, however, the gaushala has taken over 8500 cows, at which point it stops admissions and accepts only critical cases like injured animals. Lack of funds, however, hampers their functioning." The report further notes that a promised 40 rupees per cow per day from the government and a matching fund has not been received by this goshala since over a year. Turnbull (2017, p. 32) quotes a pseudonymous animal activist 'Smita': “[F] or the sheer number of animals, the number of Gaushalas [in India]...is grossly inadequate...In most Gaushalas you find they are concentration camps. You will find that the cows cannot even stand."

${ }^{16}$ The recipients of bovines had to sign an affidavit affirming their intention to follow twelve conditions of their care, including details on daily maintenance and shelter conditions, provision of medical needs, assurance that they will never be sold or slaughtered, and that the recipient will contact the goshala in the case he finds himself unable to continue caring for a bovine received from it. 
purchased, and the animals would end up on the street where they had been before arriving at the goshala the first time. Chohan comments:

It was the same story again. I found the same cows there on the road again, and they were cursing me. [The cows] were saying, "You have rescued us, you have made us healthy, and how the hell have you sent us again on the road? It is a great injustice!" They were talking to me like that. Those cows recognized me, I recognized them. So, I got them back, and I stopped selling cows. ${ }^{17}$

The problem of overcrowding in the goshala was not solved by selling cows to farmers and now, it seemed, some cows had been twice betrayed.

Today, cows in India are, as living beings with high symbolic significance, caught amidst contradictory forces. On one side is the ideology of reverence and care, coinciding with, and intertwined with, the traditional notions of dharma and bhakti. These complementary paradigms (dharma and bhakti) are seen as the force for human balance and relationship with nature's rhythms and the felicitous functioning of human beings within a higher order. Cows in particular are seen as embodying this force, and as such, they become a collective symbol of goodness. At the same time, real, living, individual cows are large, domesticated creatures requiring much care and attention by humans if they are to live well. Like any other creatures, they are prone to disease and as large animals they can, in some situations and depending on breed and other factors, be dangerous to humans. As such living beings, bovines are today subjected to a powerful contrary force which can be called the juggernaut of modernity (Smith 2003, p. 23). ${ }^{18}$ This force is set in motion by the economics

\footnotetext{
${ }^{17}$ In a later interview, Chohan explained that one reason farmers abandon cows received from his goshala is that the prohibitive cost of paying off police extortions-as much as RS 10,000 (ca. \$150) while (legally) transporting the cows from the goshala to their farms proves too much for them to bear on top of maintaining the cows.

${ }^{18}$ Smith calls attention to the origin of the word juggernaut as being the massive wooden festival chariot of the Hindu temple image named "Jagannath" (Lord of the Universe) in Puri, India. He continues, "While the original Jagannath car carried images of the gods that people worshipped, the modernity that is capitalism as it proceeds along its trajectory befuddles us with fetishisms, with factitious, fabricated images. The temple car characteristic of the lumbering, unmaneuverable, dangerous quality of Hinduism is transferred to its opposite, modernity, which is fast, unmaneuverable, and no less dangerous."
} 
of consumerism and corporate rationalism, a massive vehicle careening out of control into an unpredictable future, determining cows' lives and deaths almost solely on the basis of economics. And their value while alive is limited by goods they produce which, once no longer supplied, renders them valuable only in death, to be slaughtered for final consumption.

To be sure, some cows are not killed but, left to their own resources as strays, they may die from consuming human waste; or fortunate cows may be rescued and cared for in goshalas, but generally in overly confined spaces. And if they are very lucky, they may find a place in goshalas where they are properly fed and cared for. ${ }^{19}$ Our next task in sketching presentday cow care in India will be to get an idea of the economics of cow care projects - projects dedicated to caring for bovines throughout their natural lives. Similar to the dairy industry, some, but not all, of these cow care projects put importance on the cows' production of milk. But unlike dairies, which typically sell for slaughter the aging cows whose milk yields are diminished, cow care projects cannot (and of course are not intended to) maintain themselves in this way.

\section{The Economics of Reverence and Care}

There are different sorts of goshalas-institutions for maintenance or rescue and care for bovines in India, typically at least implicitly having a basis in Hindu identity. ${ }^{20}$ Generally, these may be categorized as either temple-affiliated goshalas or as charity-based, or vania goshalas (Nagy 2019, pp. 255-256). Temple-affiliated goshalas are maintained and funded through temple organizations, of which there are various kinds and

\footnotetext{
${ }^{19}$ Stray bovines brought to goshalas can, if the goshala is poorly funded and managed, leave them worse off than if left to wander. Such has happened recently in Vrindavan, according to the text accompanying this video https://www.youtube.com/watch?feature=youtu.be\&v=gAstcNBe5Cg\& fbclid=IwAR12LUKadQhJ0O2eiWso5beIRtEouPNsreJqCHBbIOsiNt29N_j5uX20UtY\&app= desktop (accessed 7 March 2019).

${ }^{20}$ The 2002 Indian Government Report of the National Commission on Cattle estimated 3000 goshalas, maintaining over 600,000 cattle (Kennedy et al. 2018, p. 4). Whether this refers only to officially registered goshalas is not clear. Devi Chitralekha quotes an estimate of 12,000 goshalas, contrasting this number with triple the number of abattoirs in India. Brig. Chohan mentions 6000 goshalas across India.
} 
degrees of complexity, from very small and simple temples and organizations to the grandest of temples, such as that of Venkateswara at Tirupati, Andhra Pradesh, in South India. For most temple goshalas, funding is received by the temple as donations that are given as devotional offerings to the temple image(s) or directly for cow care (go-seva). ${ }^{21}$ Vaniya goshalas are typically organized and funded by business people, often as caste-specific groups. ${ }^{22}$ In both cases, the main source of maintenance is essentially charity, although to varying degrees the goshalas may also offset some expenses by selling cow-based products, including milk, ghee, cow dung- and cow urine-based products, especially traditional (Ayurveda) medicines.

Having noted these two major types of goshalas (of which there are sub-varieties), there are other types as well, one represented by the Kamdhenu Dham Gaushala in Gurugram, previously mentioned. This is a public-private partnership of the municipal government of Gurugram and Vishnu Charitable Trust, an NGO which is responsible for daily management of the goshala. Kamdhenu Dham Gaushala maintains no dairy, concentrating entirely on rescue and rehabilitation, so it receives no income from dairy products. Currently, it receives in donations roughly one lakh $(100,000)$ rupees, or US $\$ 1400$, per month, which is around 40 rupees or half a dollar per day for each cow, covering about half the goshala's running costs. It also produces and sells dung-based compost. But, with the help of the central and state governments, there is a plan to install a biogas unit. From the twenty tons of dung produced daily, this could bring 35,000 rupees daily income. However, with no prospect for obtaining more land, this goshala's prospects for expansion, even with such increased income, are severely limited. ${ }^{23}$

Another sort of cow shelter could be called a sadhu goshala. Sadhus are Hindu renunciants or monks, and it is not uncommon for them to

\footnotetext{
${ }^{21}$ Shocking as it may be, Yamini Narayanan (2017) reports that there are temples that, having received a calf or cow from a donor in good faith that the temple goshala will care for it, will then sell it for slaughter.

${ }^{22}$ Lodrick (1981) discusses four types of goshalas: temple, court, vaniya, and Gandhian; he also discusses Jain pinjrapoles and gosadans.

${ }^{23}$ One year after my first interview with Brig. Chohan, he reported that the biogas installation remains "on paper" (and he clarified that the idea is for a central biogas processing plant that would serve several goshalas in the area).
} 
attract a following and, with followers' support, to undertake various pious projects such as the establishment and maintenance of goshalas. One such sadhu is Swami Datta Sharanananda, a tall, handsome, itinerant Hindu monk (sannyasi) who travels widely in India to propagate his message of cow protection and care. The goshala complex he has founded is a striking example of this type, the massive Shree Godham Mahatirth Anandvan in the Pathmeda district of southwest Rajasthan. In a several-hundred-acre area, some 44,000 cows and bulls are sheltered, though at one time there were more than 100,000 bovines. ${ }^{24}$ Most of these are rescued animals, of local breeds (Kankrej and Tharparkar) as well as mixed breeds. Resident cowherd families each care for some 100 bulls or oxen, or of about 40 cows. There are also varying numbers of volunteers. ${ }^{25}$ Financial support for daily operations and facility expansion comes from a broadly distributed donor base and from the sale of cow products-especially medicines, cosmetics, and other items from bovine dung and urine. Unlike the Gurugram goshala, the Pathmeda goshala has no land area constraints, with additional government land available for grazing.

As we have seen in the previous example of a rescue and rehabilitation goshala (the Gurugram goshala), here at Pathmeda also, donors play an essential role in the goshala economy. Thus, as with most goshalas, at Pathmeda there is no claim to having a simple self-sufficient economy, although the aspiration is to come to the point of growing sufficient fodder for a year-around supply. Lack of self-sufficiency can be viewed in two ways. From one side, it may be seen as a weakness that such institutions are dependent on constant outside charitable support. On the other side, the receiving of charitable assistance may be seen as a positive function of the institution, namely as a means by which (generally urban-dwelling) persons otherwise disconnected from cows are able to feel some connection with them and therefore blessed by them.

\footnotetext{
${ }^{24}$ The Shri Pathmeda Godham began in 1993, initially with eight cows. It is reported that in 2002-2003, during a "disturbed time" (bhīsana-kälmen) 182 temporary and permanent centers for cow care were established, with a total of some 280,000 bovines (Dattaśaranānand, Samvat 2073). The Pathmeda Trust has three main goshala centers under its direct control, and some 64 smaller goshalas in the area are assisted by the Trust.

${ }^{25}$ The institute identifies three types of workers: (1) unmarried male student volunteers (brahmacaris), (2) older volunteers (vanaprasthis), and (3) paid workers.
} 
Since charity is central to much goshala economics, to get a comprehensive picture of goshala functioning it is important to think about donors. To this end, I introduce two brothers, Arvind and PrabhavMumbai industrialists who have become closely involved in support of the Pathmeda goshala project.

When they first heard about the Pathmeda goshala in 2011, Arvind and Prabhav's mother was inspired to "adopt" ten of the goshala's cows. (Cow adoption is a scheme that is used in some goshalas as a means to ensure steady charity income. ${ }^{26}$ Eventually, they visited Pathmeda. Arvind explains,

At Pathmeda we found tan-man-dhan [Hindi, literally "body, mind, wealth," namely, the opportunity to give service with these three capacities] ... We asked the Swami [Swami Datta Sharanananda, founder of the goshala] if there is something we can do, and he kindly appointed me as the caretaker for all injured cows. So, we built a hospital there ... that takes care of one thousand cows per day, treated by allopathy, Ayurveda, homeopathy and raga-chikitsa (music therapy).

The two brothers have also initiated a small enterprise intended to bring income for the goshala and, at the same time, give cow products' customers a sense of direct connection to the cows. The products are ritual items made with cow dung. So, for example, they produce small cow dung images of Ganesh, a divinity that is widely worshiped by Hindus, especially in Maharashtra (the state in which Mumbai is situated). They have also begun producing bovine fuel briquettes for cremation. Arvind explains his concept for using these briquettes to raise substantial funds for cow protection:

[I thought,] can I write in my will, stipulating that my last rites (of cremation) shall be performed with these bull dung logs? If one percent of Hindus

\footnotetext{
${ }^{26}$ Typically, a person or family adopting a cow will commit to providing sufficient funds for maintaining a particular cow for life. The donors are encouraged to visit "their" particular cow or cows at the goshala, and they are kept informed about their welfare. At some goshalas, if it includes a dairy, the donor may receive regular "gifts" of dairy products. Especially, if it is a goshala connected to a temple, the donor may receive sweets made from the goshala milk that has been consecrated in offerings to the temple divinity.
} 
would commit to this, and 250 kilograms [of these logs] are needed to cremate one human corpse, we can save fifteen lakh [1.5 million] bulls [with the money paid for the fuel]. Gurus can tell their followers to have this written in their last will and testament. ${ }^{27}$

Such ideas are conceived on the basis of producing value-added products that are directly from the cows that are being cared for-substances that are then moderately processed, without addition of chemicals. Customers (donors) can be expected to pay relatively high prices for such items, being confident that the profit is going toward the care of cows throughout their natural lives. ${ }^{28}$ Thus, to purchase these products is to be also a patron of the cows, through the institution that sees to their care. Broadly speaking, it may be said that the value added to such products is the ideal of ahimsa, the dharmic, ethical value of nonviolence, regarded as the highest form of dharma. Yet for many customers the added value includes an element of bhakti, devotion, in the sense that they see themselves contributing to go-seva, service to cows.

While reckoning anticipated gain from their new enterprise, Arvind and Prabhav emphasize the moral imperative that all profit from such cow dung products must go exclusively for the care of cows:

We don't do business with our mother, so how can we do business with go-mata [mother cow]? So, we have to be clear that everything we do, we do for free. There are two principles—-honest earnings and selflessness. ${ }^{29}$

\footnotetext{
${ }^{27}$ A similar idea has been taken up by students in Delhi (IIT Delhi Students 2018).

${ }^{28}$ These Ganesh images (murtis) are actually made from the dung of calves, which is especially viscous, making it possible to form the images without any additives. Ganesh worship is especially popular in Maharashtra, and particularly on Ganesh Chaturthi, in August or September, when thousands of temporary images of the "elephant god" are made and then, after the festival, submerged in the sea or in a river, with considerable polluting effect. Such pollution is avoided with the Pathmeda cow dung images.

${ }^{29}$ As may be expected, not all goshalas in India function on such a high level of ethical practice. Nor is it always clear where the ideals of cow care give way to profit motive. The Gurugram goshala is recognized as a model goshala for the country, and this suggests there are many that are far from the ideal (Turnbull 2017). Further, standards in a given goshala may change over time, depending on management changes and other factors.
} 
And yet this sense of dharmic business ethics on behalf of cows is, for these industrialists, only a stop-gap intervention. From a broader perspective, such business arrangements are, at best, emergency adjustments to the demands of the modern globalized industrial economy. They serve to optimize conditions for cows within a system that is deeply inhospitable to the culture of cow care. What is urgently needed, they feel, is the recovery of a self-sustaining, cow-based agrarian economy, as has existed for untold centuries of India's past.

We begin to see that many sorts of people become involved in cow care, from founders of goshalas to managers, what to speak of workers (hired or volunteers), donors, and less directly, any number of persons involved in supply provision or doing business with or enabling wealth for donors. Yet for many Hindus engaged directly in cow care in India, there is another person involved in a crucial way, namely the Lord of the Cows, Krishna, or his divine consort Radha (known also as Radharani). This was explained to me by the manager of a moderate-sized goshala on the outskirts of Vrindavan, famous as the land of Krishna, as we discussed his donor base (see Fig. 4.1). Keshi Nisudan Das, the manager of Care For Cows, ${ }^{30}$ first expresses appreciation for his workers:

[Our workers] love the cows. When you love the cows-everybody is loving - the Lord is pleased. And when the Lord is pleased, there is no limit to what we can get. But it has to be sincere service. You must be able to sacrifice twenty-four hours a day and dirty your hands.

"What we can get" refers to support for maintenance of the goshala, pointing to Care For Cows' essential source of support, sympathetic donors. Strikingly, unlike most other Indian goshalas, Care For Cows is supported largely by an international community of people valuing their cause (hence the goshala's English name). Their financial contributions allow the onsite caretakers to continue their close attention to the cows. Conversely, the

\footnotetext{
${ }^{30}$ Care For Cows was founded in 1999 by Kurma Rupa Das, an American member of ISKCON (Hare Krishna Society) who had lived in Vrindavan for thirty years. In 2015, he breathed his last while staying with his cows at Kiki Nagla, Vrindavan. The CFC Newsletter, November 2015, a special in memoriam issue, quotes the Brahmanda Purana (21.93): "A place where cows stay is considered sanctified, and a person who dies there certainly attains liberation."
} 


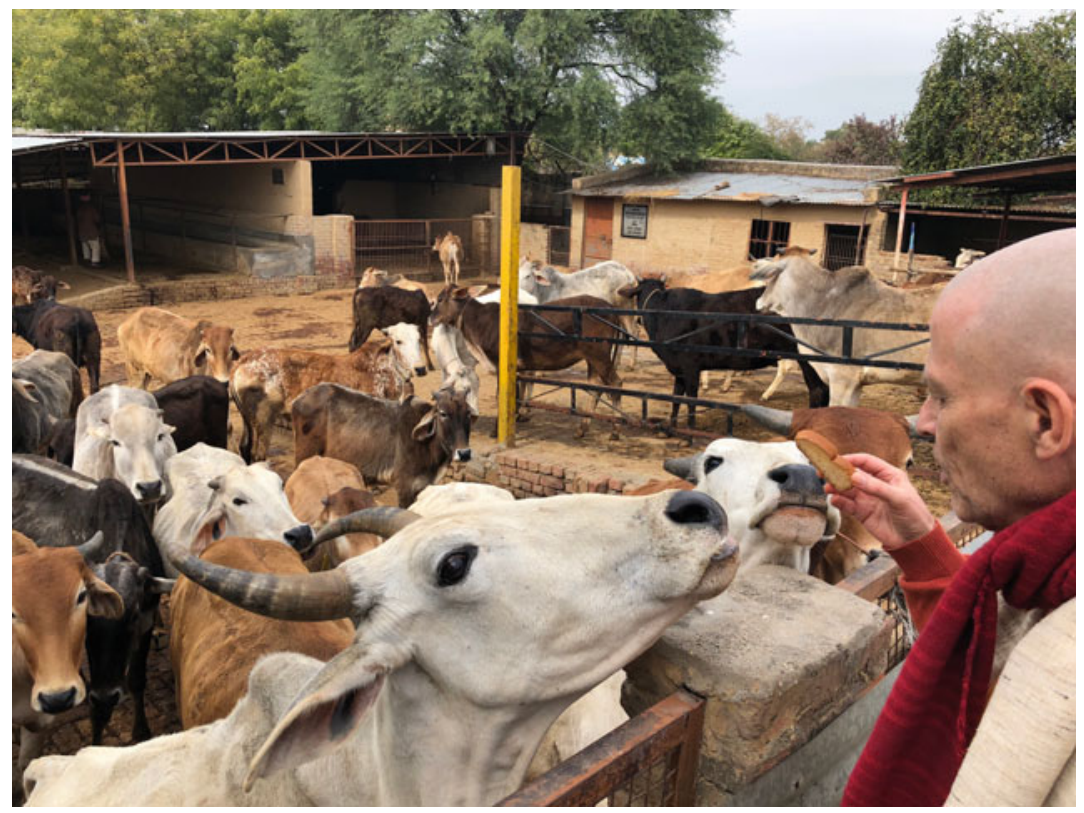

Fig. 4.1 The author offers a snack to rescued cows at Care For Cows, Vrindavan

international supporters feel encouraged that they are benefited by serving Krishna's cows, even if indirectly, from a distance. ${ }^{31}$ As in Pathmeda, regular donors may "adopt" a specific cow, enabling them to experience a sense of connection with a particular bovine, to receive news about it, and when visiting Vrindavan, to directly meet and interact with their adoptees. ${ }^{32}$ Donors have also been recognized in the (currently discontinued) monthly newsletter. However, a good number of visitors may give

\footnotetext{
${ }^{31}$ One striking example of a foreigner in India dedicating her life to cow rescue and care is Sudevi (Friederike Irina Bruning) from Germany. Since 1996, Sudevi runs Radha Surabhi Gaushala Niketan, near Radha Kunda (near Vrindavan), presently with 1800 cows. In 2019, in recognition of her dedication to this service, she received the Padma Shri award, the Central Indian Government's fourth highest civilian honor.

${ }^{32}$ Keshi reports that of more than 500 cows maintained in Care For Cows, some 250 are sponsored. Nine-tenths of monthly donations are spent on maintenance and the remainder goes into savings or for new construction. Keshi says, "For the monthly expenses, we somehow manage. It's tough, I have to work very hard. First thing in the morning, I come to my cows and say 'Hey, how much are we going to get today?' because we need such and such amount. We pay our staff well ... and medicine last month took a big chunk. We feed our cows three times a day-we don't want to be stingy; we buy them enough, we feed them enough."
} 
donations expecting no receipt or mention. Keshi likes to say that such donations are coming from Krishna's divine consort, Radharani (Radha).

From the bhakti perspective, this reference to Radha says that ultimately, because she is the divinity who oversees service to Krishna, especially in Vrindavan, it is by her grace that sufficient sponsorship comes to maintain what Krishna's devotees regard as Krishna's cows. According to Vaishnava theology, as the ultimate form of the divine feminine, it is she who "expands" as Lakshmi, who governs worldly wealth and opulence. Significantly, Lakshmi is associated with cows, and in delineations of the several divinities' specific locations in cows' bodies (as discussed in the beginning of Chapter 3), Lakshmi is located in the dung. Care For Cows generates a modest income for the goshala from the sale of dung to locals who use it for fertilizer. But Keshi emphasizes the goshala's focus on service as pleasing to Radha and therefore pleasing to Krishna, rather than on gain from the cows: "We don't want to go into business, because then our concentration on service becomes diverted. Then we will be thinking (only) of money. Money is essential, but then making money is a different, mundane activity."

While the spirit of service may dominate in cow care, there is no denying a strong emphasis on bovine products as affording multiple benefits for humans. Thus, invariably connected with goshala economics are considerations of these benefits. And although goshalas (such as Kamdhenu Dham in Gurugram) may not maintain dairies, others, such as the Pathmeda institution, do so as an essential practice. Beginning with cow milk, followed by the milk derivative ghee, and then dung, urine, and the mixture panchagavya, we can now consider how these products are regarded and used in India, keeping in mind the question whether, how, or to what extent it may be appropriate for humans to use bovine products. This question will occupy us on a theoretical level in Chapter 5 . Here it bears brief mention that the ethical framework assumed for bovine product use is largely that articulated by M. K. Gandhi, who regarded India's predominantly rural civilization as "essentially non-violent" and "wrapped up with [its] animals" (quoted in Nagy 2019, p. 252). As "utilitarian protectionism," the view is that human utility can be accomplished with bovine 
well-being and benefit when well cared for throughout their natural lives (Nagy 2019, p. 255). ${ }^{33}$

\section{Bovine Products as Added Value}

\section{Milk}

As we saw in Chapter 2, cows (and the several words for "cow") in ancient India carried an extensive field of cultural meaning, and the same was true of cow products, especially milk and its derivatives, as indicated, for example, in the Mahabharata: "Kine by yielding milk, rescue all the worlds from calamity. It is kine, again, that produce the food upon which creatures subsist" (Ganguli 1991, vol. 11, p. 94; Mahabharata 13.71).

In the present day, along with multiple meanings of bovine dairy products, there are also multiple disagreements about their value and use. Some disagreements relate to human health and cow milk consumption, such as whether it is at all necessary for humans ${ }^{34}$; whether it is necessary to nourish specific bodily organs, such as for brain development; whether milk should be pasteurized or homogenized; and whether milk containing betacasein protein A1 is a cause of certain diseases, in contrast to beta-casein A2 milk (an issue linked to the distinction between nonindigenous cows

\footnotetext{
${ }^{33}$ In contrast to this "rights without liberation" ethic of utilitarian protectionism, which we will consider more extensively in Chapter 5, Nagy (2019, p. 255) identifies two other ethical position types regarding bovine treatment, namely an "industrial animal-welfare science" ethic rooted in American agribusiness husbandry and an "abolitionist animal rights" ethic, which calls for the complete cessation of animal product use and the adoption of a vegan lifestyle.

${ }^{34}$ Lactose intolerance, a common condition, has been seen to arise naturally in humans as they grow out of infancy, as an indicator that it is no longer needed beyond infancy. Yet this intolerance can be overcome by boiling the milk-a standard practice in India to the present day, in which after boiling up, it is kept on a simmer for 5-10 minutes, allowing a molecular structural change to occur making it digestible (Velten 2010, pp. 21-22, 25). According to traditional Indian medicine (Ayurveda), milk can serve medicinal purposes, especially as a rejuvenator, but also as an aphrodisiac (Rastogi and Kaphle 2011). An Adventist Health Study project found that "Those drinking more dairy milk have lower rates of colon and rectal cancers (but preliminary findings suggest increased risk of breast and prostate cancers)" (Banta et al. 2018, p. 13; Jacob 2014, pp. 111-118). See also Marshall (2019) for a very brief overview of prehistoric to present-day use and attitudes toward animal milk.
} 
and indigenous cows, the latter regarded as producing only A2 milk). ${ }^{35}$ Also related to cow milk use in India is the issue whether buffalo milk is beneficial or detrimental for humans, and under what conditions. ${ }^{36}$

These are contemporary issues surfacing in post-industrial societies, including India. ${ }^{37}$ Prior to this, in some but not all parts of India, bovine milk has been highly valued for rituals and for nourishment, especially of young children, often regarded as a necessity for their survival when mother's milk is inadequate. With a lack of refrigeration, milk was invariably turned to yoghurt if not immediately used or else immediately cooked (usually with grain). Processing milk to yoghurt and then to butter by

${ }^{35}$ See, for example, Sun et al. (2016), a study in China which concluded (p. 1 of 16, Abstract), "Consumption of milk containing A1 B-casein was associated with increased gastrointestinal inflammation, worsening of PD3 symptoms, delayed transit, and decreased cognitive processing speed and accuracy. Because elimination of A1 $ß$-casein attenuated these effects, some symptoms of lactose intolerance may stem from inflammation it triggers, and can be avoided by consuming milk containing only the A2 type of beta-casein." Tangentially related, animal welfare activist and researcher Maneka Gandhi offers interesting advice, namely to drink camel milk, it being the most healthy in several ways, including being a "superfood" for diabetics. See "I never thought the day would come when I would recommend the drinking of milk!" at https:/www.peopleforanimalsindia.org (accessed 7 February 2019). See also Pallavi (2015) for a brief overview of the A1-A2 discussion; the economic difficulties of Indian farmers, herders, and nomadic pastoralists who maintain indigenous cattle breeds; and research being done on milk properties of these breeds, particularly of the Gaolao breed, taking into account traditional knowledge thereof.

${ }^{36}$ On buffalo milk, see Sinha (2016), pp. 173-175. Sharma (1980, pp 175-181), discusses milk and ghee benefits in modern medicinal terms, citing Sateeshchandradas Gupta, The Cow-in-India vol. 1. Calcutta: Khadi Pratishthan, 1945. Also interesting if vague (given without specific reference) is Sharma's claim, that "[M. K.] Gandhiji [Gandhi] and S.C.D. Gupta collected experts' opinions and elaborately demonstrated and proved the superiority of cow milk to buffalo milk" (Sharma 1980, p. 8).

${ }^{37}$ Many cow care activists in India refer to scientific research to support various claims, especially about the benefits of cows' milk, bovine dung, and urine. A valuable discussion of modern science in the context of cow care would, if space would permit, consider how basic presuppositions of mainstream modern science lead to production of knowledge inherently opposed to traditional forms of knowledge whereby bovines are recognized to be integral to the maintenance of ecological balance in agriculture. See Shiva (2016, Chapter 1), "Agroecology Feeds the World, Not a Violent Knowledge Paradigm," and passim. This issue intersects with the broader theme of power/knowledge relationships with respect to the environment and the treatment of animals. For an extended analysis of the latter (animals and knowledge systems), see Johnson (2012). For a broad overview of the Hinduism and science discourse, see Dorman (2011). 
churning has, as a common domestic activity, been enshrined in classical literature, as we saw in Chapter 2 with the story of Krishna breaking his mother's churning pot and stealing the butter (Mahias 1987, pp. 285-286). ${ }^{38}$

Of ethical concern for Hindu cow carers today-assuming that cows are cared for throughout their natural lives - is how much milk may appropriately be taken from cows in relation to how much milk should be reserved for their calves. The ancient Sanskrit guide to governmental management, the Arthashastra of Kautilya (ca. 4th c. CE) gives an interesting injunction that may be relevant: In the rainy season, autumn, and early winter, cows and she-buffaloes are to be milked twice per day; all other seasons, once per day (Tiwari, n.d.; Rangarajan 1992). ${ }^{39}$ Some of the cow carers I interviewed emphasized that milk remaining after calves have their fill should be regarded as a "bonus" that is not to be expected, but rather graciously accepted along with the many other benefits of having and caring for bovines. They also point out that any restriction of milk imposed on a calf in its first months will effectively backfire, as the calf will be deprived of its full natural development and thus will be less productive in later life. ${ }^{40}$ They expressed sadness that some cow carers breed bovines with the intention to increase milk yield. But then such breeders will say that they are not depriving calves of milk by intentional breeding for greater milk yield, and that this is not an improper imposition on cows. Rather, it is a response to an increasing demand-based on a genuine need-for pure milk from cows that are cared for throughout their natural lives. ${ }^{41}$

Interviewees who see themselves as sympathetic to cow protection typically expressed regard for milk from lifetime protected cows as "added

\footnotetext{
${ }^{38}$ The churning image has wide resonances in Indian literature, famously in this account, but also in the story of cosmic churning described in several early texts, including the Bhagavata Purana.

${ }^{39}$ Punishment for milking twice a day in the wrong season could be harsh for a cowherd of the king's cows, namely the loss of his thumb! Those tending the royal herd were paid in cash rather than in milk and ghee, to allay the possibility that they would otherwise limit the calves' milk to get a higher yield for themselves (Rangarajan 1992, pp. 88, 96-97).

${ }^{40}$ Dayal Mukunda Das interview, 10 January 2018; Sinha (2016, pp. 111-113).

${ }^{41}$ https:/www.youtube.com/watch?v=um5Cj5B7LoQ\&feature=youtu.be (ca. 5:30:00; accessed 26 November 2018). In this Cow Culture Conference talk, May 20, 2018 (Silicon Valley), Balabhadra Das, an American Vaishnava, gives pause for thought on milk production: "In Vedic times, cows were not bred for milk, they were bred for bulls, manure, and urine... Milk will come automatically, it is not our main concern. Our main concern is bulls."
} 
value" milk that is especially healthful and nourishing. One reason given is that protected cows are surely aware of their protected condition, an awareness that plays out in unstressed body chemistry and in a relaxed sort of interaction of the cows with humans. ${ }^{42}$ At the least, they point out, such milk is free from the several adverse substances imposed on industrial dairy cows, such as added hormones and antibiotics.

Most importantly, conscientious Hindus regard such milk to be infused with an ethical value enshrined in the principle of nonviolence, and they regard such "ahimsa milk" as therefore also having important medicinal properties. ${ }^{43}$ Thus, milk and milk derivatives in general are most valued when obtained from protected cows. ${ }^{44}$ This also explains why many of the larger Hindu temples in India (and, since more recently, elsewhere in the world) maintain goshalas with milking cows. For offerings of food preparations to temple images of Krishna, devotees favor preparations featuring milk and milk derivatives, thereby honoring his celebrated preference for these as a child. This understanding of Krishna's milk preference contributes to the sense that the temple cows are venerable as Krishna's cows, and that their daily care (go-seva) counts as service to Krishna, since the cows in his domain are especially dear to him (see Figs. 4.2 and 4.3).

\section{Ghee}

The derivative of milk—ghee (ghrta in Sanskrit, clarified butter or anhydrous milk fat)—is the bovine product most specifically associated with Hindu culture. Some twenty-five liters of milk are required to make one

\footnotetext{
${ }^{42}$ Several cow carers interviewed pointed out cows in their care who were continuing to give milk years after their last calf-considered a clear indication that these cows are not only peaceful but happy to show their generosity in this way.

${ }^{43}$ Two Indian cow carer interviewees told of a tradition that, in earlier times, if a child in the household fell ill, the elders would whisper the nature of the illness in the ear of a family cow. This cow would then proceed, while grazing in open pasture or forest, to select certain herbs that could benefit the child, such that when the child would be fed the cow's milk from that evening's milking, it could be cured of the illness. This seems related to the tradition of wish-whispering in the ear of Shiva's bull image.

${ }^{44}$ Sitaram Das, who operates Ahimsa Milk dairy near Leicester, UK, says that he cannot keep up with the steadily rising demand for his products from fifteen cows. Despite his unavoidably high prices and membership fees, these products are valued specifically due to the "slaughter-free milk" standard. https://www.ahimsamilk.org/ (accessed 30 November 2018), and personal interviews.
} 


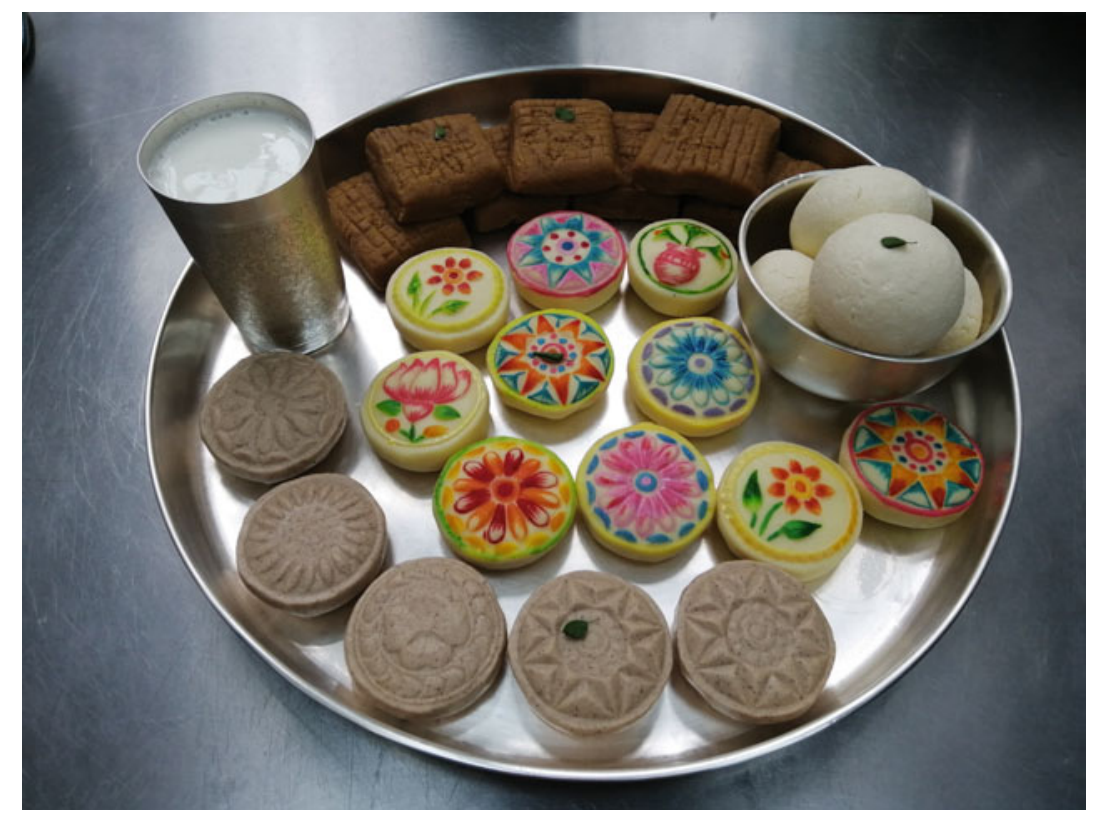

Fig. 4.2 Artfully prepared dairy sweets and hot milk for Krishna's daily early morning snack, at Bhaktivedanta Manor, near London

liter of high-quality ghee, ${ }^{45}$ an indicator of how highly ghee is valued. Ghee is valued for three areas of use, namely for ritual purposes (especially for making ghee oblations into a sacred fire); for cooking-both for deep-frying and for sautéing; and for medical purposes, especially as a component of Ayurvedic medicines. ${ }^{46}$ Because ghee can be stored for long periods and can be easily transported, it has long functioned in India as the main end-product of milk (Rangarajan 1992, p. 82).

Ritual use of ghee is invariably in relation to the performance of fire rites (yajna; homa), which we have already discussed as defining practices of the orthodox brahmanical tradition that later develops as the Hindu

\footnotetext{
${ }^{45}$ Damodar Dulal Das, Sri Surabhi Conference, https://www.youtube.com/watch?v= um5Cj5B7LoQ\&feature=youtu.be (accessed 31 May 2018).

${ }^{46} \mathrm{On}$ the use of ghee in Ayurvedic medicine (and a detailed explanation of the traditional Indian way of preparing it), see Malakoff (2005).
} 


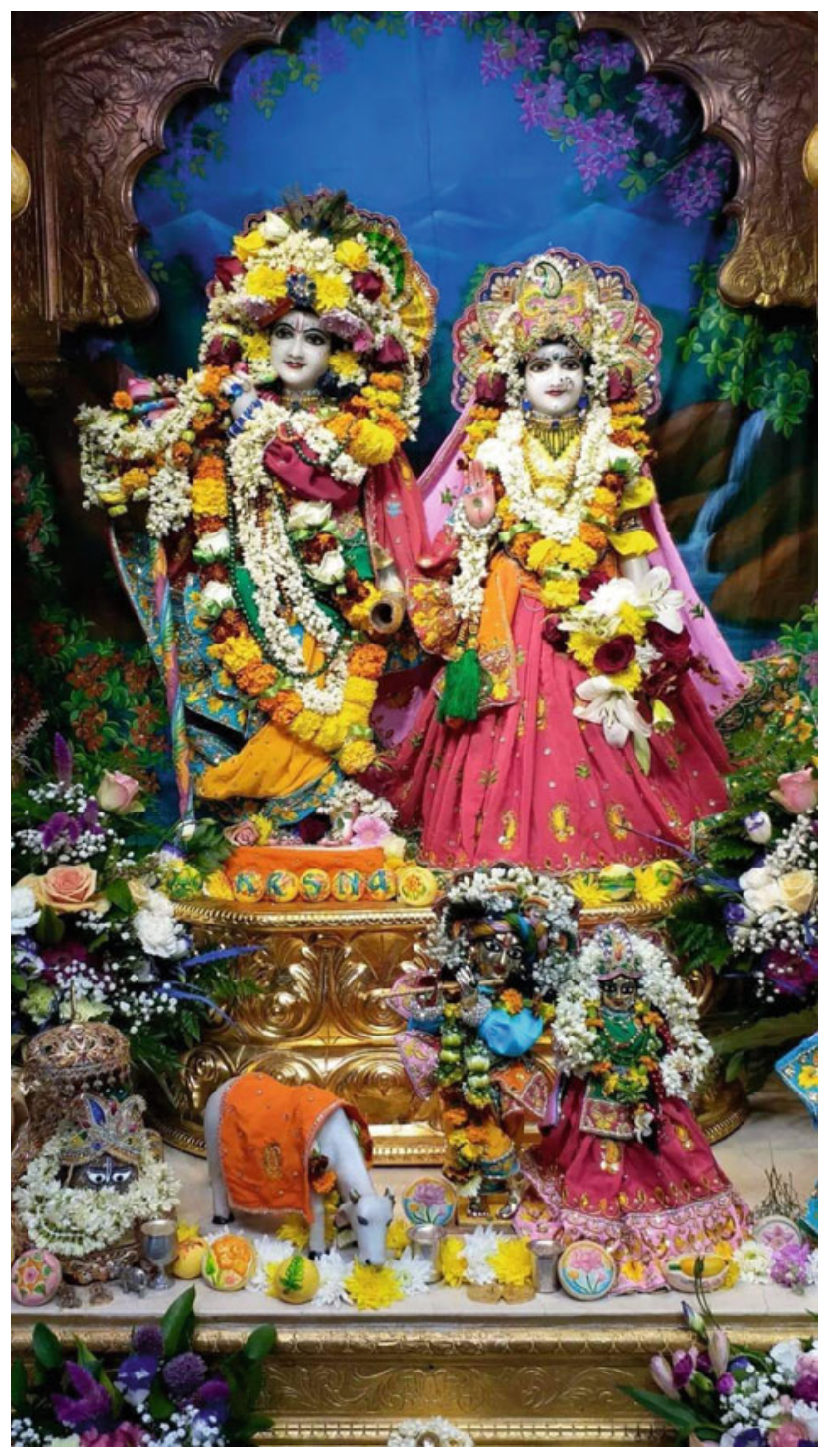

Fig. 4.3 Temple images (murtis) of Radha-Krishna at Bhaktivedanta Manor, rendered seven vegetarian food offerings daily 
constellation of ideas and practices. ${ }^{47}$ To be noted here is that ghee will be used in a variety of present-day Hindu rituals, including several rites of passage (samskaras) of which the wedding rite is central. Further to be seen as a ritual use of ghee is to give it in charity, an act much praised in the Mahabharata. ${ }^{48}$ As for ghee in cooking, it is especially used on occasions of celebration, such as weddings, when abundance is particularly highlighted through the medium of rich vegetarian food. Further, ghee signifies food purity, especially of preparations that use it for deep-frying. ${ }^{49}$ In Vaishnava bhakti traditions, ghee is generously used in temple cooking, as it is understood that Krishna is particularly pleased by food offerings prepared with ghee. ${ }^{50}$

In recent years, several proponents of cow care have been championing the medical benefits of cow ghee. But for ghee to have the desired medical benefits, as noted by Damodar Dulal Das, a leader of ISKCON-India's cow care projects,

the cows (from which the milk has been taken, for making the ghee) have to be happy cows. First, we feed our calves with the full milk content from two of the mothers' four teats, so we don't deprive the calf of her milk. It is a

\footnotetext{
${ }^{47}$ Vedic texts prescribe ghee to be offered in the fire, as fire is the divinity Agni, who is "fed" in this way. Ghee is regarded as virya - potent—and as such purifying to the immediate ritual space of the fire rite, and purifying to the surrounding area. My thanks to Dr. Shalvapille Iyengar for this explanation. We may add that ghee's potency derives from its being the essence of an essence-the essence of milk, which is seen as the essence of the grass and other nourishment eaten by the cow. ${ }^{48}$ In the Anushasana Parva, Bhishma tells Yudhisthira, "Ghee is said to gratify the illustrious Vrihaspati, Pushan, Bhaga, the twin Aswins, and the deity of fire. Ghee is possessed of high medicinal virtues. It is a high requisite for sacrifice. It is the best of all liquids. The merit a gift of ghee produces is very superior. That man who is desirous of the reward of happiness in the next world, who wishes for fame and prosperity, should with a cleansed soul and having purified himself make gifts of ghee unto the Brahmanas. Upon that man who makes gifts of ghee unto the Brahmanas in the month of Aswin, the twin Aswins, gratified, confer personal beauty. Rakshasas [ogres] never invade the abode of that man who makes gifts unto the Brahmanas of Payasa [sweetened rice] mixed with ghee" (Ganguli 1991, vol. 11, p. 79; Mahabharata 13.65).

${ }^{49}$ Food categories may turn on whether something is prepared with water (usually boiling) or with ghee (typically deep-frying). Water, among other items, is considered disintegrating, whereas ghee is a preservative, making it especially fit for public (festival) events (Toomey 1994, pp. 49-50).

${ }^{50}$ There are two explicit mentions of ghee in the Bhagavata Purana. One (6.19.22) enjoins preparing rice cooked with ghee to offer as oblations in a ritual home fire, as part of a practice to prepare for having a child. The other verse (11.27.34) includes ghee in a list of preparations recommended for offering to a temple image of Krishna.
} 
[function of] hormonal secretion. As much as the cow is happy, that much the hormone will be secreted by which she will give that much milk. ${ }^{51}$

The idea is that when cows are well treated and thus peaceful, and their calves are properly cared for and generously fed, the milk yielded by such cows will be of the best quality for producing high-quality ghee.

According to Damodar Dulal and another, widely known activist for cow care in India, Uttam Maheshwari, the medical benefits of high-quality ghee are numerous. While evidence of benefits tends to be anecdotal, ghee is recognized as an important healing agent in Ayurveda- a traditional Indian medical system - and some modern research has been done pursuant to verification of its efficacy. ${ }^{52}$

Some cow care institutions that have lactating cows and which have dairy facilities make ghee and offer it for sale to the public. Typically, such ghee will be sold at a considerably higher price than the same from an ordinary dairy, as a value-added product. ${ }^{53}$ As noted regarding the valueadded cow dung products of Pathmeda, what is understood to be the specific added value is the conscientious lifelong care for the cows from which the milk - and therefore the ghee-has come. And such conscientious care translates into a sense of ethical rightness for the ghee customers and a sense of quality - that the ghee, coming from cows that are contented, will be most efficacious in its various uses.

\footnotetext{
${ }^{51}$ Also considered essential by cow carers to ensure that milking cows are "happy" is that the milking of them is never to be done by a milking machine, but always by hand (although one interviewee, who found it necessary to use a milking machine because of having developed carpal tunnel syndrome, told me that his cows "did not object at all" when he began using it with them). Most importantly, several interviewees insisted that cows are aware if they are being given natural lifetime care or not. Thus, cows can only be "happy" if cared for to their natural end.

${ }^{52}$ Several Ayurvedic texts refer to ghee and its benefits; broadly, ghee serves as an "increaser" or tonic (vardhaka), in particular of the "seven essences" (sapta-dhatu) of the physical body. The Go Vigyan Anusandhan Kendra's publication "Research Activity Book" (pp. 65-73) includes lists of several preparations made with ghee including "household remedies" for several conditions. It also mentions some efforts to conduct studies of certain possible benefits, including the claim that regular ingestion of ghee can benefit intelligence. Anecdotal stories of remarkable cures of serious conditions with the help of ghee are told by some cow care activists in India. There are, for example, accounts of persons becoming free from epileptic seizures or waking from protracted comatose states as the apparent result of simply applying such ghee in one's nostrils. Such possibilities may be worth investigating.

53 In India today, ghee is priced in a wide range, from ca. Rs. 300 to Rs. 1500 for $500 \mathrm{ml}$.
} 


\section{Dung and Urine}

We recall the association of goddess Lakshmi with cow dung. Arguably, the most valuable products of bovines — female and male—are their body wastes. Throughout South Asia, one sees a standard type of village energy storage in the form of cow dung or buffalo dung patties drying on walls or, once dried, stacked neatly in large piles, ready for use as cooking and heating fuel. Dung may also be used to produce methane gas fuel, as we noted in connection with the Kamdhenu Dham Gaushala where, in addition, it is used in making compost.

At one project, the commercial Two Brothers Organic Farm (near Pune, Maharashtra), cows are maintained not for their milk, which is considered a "by-product," so much as for their dung and urine, from which fertilizers are prepared for their farm. The cows, which are of the northwestern Gir breed, graze freely on portions of the farm's land, otherwise receiving organic fodder from the farm's two acres reserved for this purpose. The dung and urine (which are swept together into a trough in the cow shed and then processed into slurry as a methane gas plant by-product) are used as an "inoculation" of healthy bacteria into the farm's soil. A guide explains that the Gir cows' ageless acclimatization to this area makes them ideal for generating a high density of healthy bacteria released into the dung. ${ }^{54}$ The resulting fertilizer makes the soil exceptionally healthy, unlike chemical fertilizers, which destroy rather than fostering microbial life for healthy farm produce. ${ }^{55}$

As Lakshmi is understood to be present in bovine dung, Ganga Devi, the life-giving and preserving River Ganges divinity, is understood to be present in bovine urine. While cow urine may be used with dung to produce fertilizer, it can also be collected separately (from my observation, not without considerable patience of a person waiting behind the cows with a bucket in the very early morning!) for medicinal use. Its medicinal value

\footnotetext{
${ }^{54}$ The guide also notes that the Gir breed's intestines, being longer than the Western cows such as Jersey and Holstein, are better able to process the local fodder, thus producing richer dung from a thorough digestive process. Further, they have a very balanced $\mathrm{pH}$ of around 7, most favorable for good bacteria. https://twobrothersindiashop.com/ (accessed 15 March 2019).

55 See Note 58 below.
} 
is signaled in Ayurveda texts by its being referred to as sanjivani (comprehensive life-giving tonic) and amrita (elixir of immortality). Especially in distilled form, go-mutra ark - cow urine extract—is recognized for treatment of kidney disorders and diabetes mellitus (Somvanshi 2006). It is also considered beneficial against several other conditions, not least cancer, which we will discuss further in the next section (Mohanty et al. 2014).

\section{Panchagavya}

The three bovine products—-milk, dung, and urine-are valued individually, and they are also valued in a mixture called panchagavya ("having five bovine substances") that includes two derivatives of milk, namely yoghurt and ghee. Panchagavya is especially valued both in traditional Ayurvedic medicine and in ritual, and also as a basis for soil fertilizer. ${ }^{56}$ Today, medicinal properties of panchagavya are especially highlighted by cow carers and activists in India, who refer to Ayurvedic reference and to modern research studies. So, for example, the Go Vigyan Anusandhan Kendra in Nagpur (central India) credits panchagavya with aiding in the cure of numerous conditions, ranging from dandruff to rheumatoid arthritis to kidney stones and heart conditions (Research Activity Book, n.d., p. 2). And beyond these claims, there are claims and accounts of panchagavya cures for cancer. ${ }^{57}$

Several organizations in India, including for-profit businesses, produce medicines, and other products, use panchagavya (or one or more of its

\footnotetext{
${ }^{56}$ The ritual use is described in such texts as the Padma Samhita (from prior to eighth century $\mathrm{CE}$ ), in particular as an important liquid substance to be poured on a temple image at the time of consecration or renewal. The text gives preference for all ingredients of panchagavya to be fresh and all from the same cow, which "should not be weak, old, pregnant, or without calf." Specific proportions of each ingredient are given, with increasing multiples from yoghurt to ghee, milk, urine, and finally (liquid squeezed from) dung. (Padma Samhita, Charyapada 8, vv. 118-130; Padmanabhan 1982, pp. 82-85; my thanks to Brahma Muhurta Das for this reference). Another ritual practice with panchagavya takes place after cremation rites, whereby ashes from the deceased are mixed with panchagavya prior to submerging the ashes in a sacred river. See Satyanarayana et al. (2012, pp. 62-63) for a detailed panchagavya preparation formula for fertilizer and a chart of its effect on micro-organisms. Another formula, from Dr. K. Natharanjan, is available here: http:// www.newdelhitimes.com/the-utility-of-panchgavya/ (accessed 16 July 2018).

57 Two examples of studies done on the efficacy of panchagavya or cow urine in cancer therapies are here, both cautiously indicating positive efficacy: Dhama et al. (2005) and Jain et al. (2010).
} 
ingredients — especially cow urine) as a key ingredient. Such products are being widely marketed in India and in other countries. ${ }^{58}$

The common thread running through our discussion of bovine products is that the benefits of living bovines for humans and the environment cannot be measured with any one product, or even all combined, against supposed "benefits" of slaughtered bovines. Despite the difficulties of caring for cows, conscientious Hindus will say that care is far better than no care, and the fact that bovines yield products beneficial for humans is an added indicator of this. Brigadier Chohan, the manager of Kamdhenu Dham Gaushala (which does not run a dairy), put it this way, reflecting on the goshala's overcrowded condition in the face of a demand for more stray cows to be sheltered:

If I say "no, I won't take [in more stray cows]," they will all be slaughtered. Which is the bigger crime, which my soul will not accept? At least their health is being looked after here. Their medicines are being given-they are very healthy. You will see [the cows] are laughing! So, it is a small price to pay [to avoid] their slaughter.

To be sure, one may object that the essentially anthropocentric character of such a care ethic is exposed as soon as there is any mention of bovines' benefits for humans. Yet arguably the ethical framework of cow care and protection is broadly dharmic, which is to say observant of regulation for human-animal coexistence in pursuit of the nonviolence ideal of ahimsa. How seriously and effectively this ideal is pursued will vary with different cow carers and organizations. Unfortunately, what goes under the name of cow care can, in some cases, look more like cow neglect or even cruelty. ${ }^{59}$ Related to this issue, we must now proceed to another, possibly more

\footnotetext{
58The Go Vigyan Anusandhan Kendra (based near Nagpur, Maharashtra) is one prominent organization among several in India promoting cow products as medicine. Such products are fairly popular; yet one interviewee, a descendent of a several-generation family of Ayurvedic doctors, Sachi Kumar, expressed reservations about their value: First, traditionally, no bovine products were sold; second, benefits of these medicines are exaggerated, as much more benefit will come from eating organically grown produce that has been fertilized with cow dung and urine than from taking medicines containing these ingredients; and third, the claim that only deshi (indigenous) cows' products are medicinally beneficial may be exaggerated.

${ }^{59}$ See Nagy (2019, pp. 252-253) on Gandhi's sharp criticism of Hindu hypocrisy and "criminal negligence" with respect to bovines.
} 
challenging, area of discussion, namely the keeping and engagement of male bovines for work.

\section{Male Bovine Care and the Issue of Violence}

India has been a land of subsistence farming throughout most of its history, and oxen, or bullocks, have done most of the ploughing, farm goods transport, and grain threshing that has made such farming possible. Since recent decades, in much of India, the same work is being done by tractors and other machines. Thus, where male bovines were once essentialeven considered more important for agricultural economy than milk cows (Chakravarti 1985, p. 33) — they now become superfluous. And being so, unless kept as stud animals, bulls become the victims of early slaughter. That such profound change in India's agricultural landscape went initially unnoticed is suggested by Rudyard Kipling in his poem "What the People Said," at the time of Queen Victoria's Jubilee, in 1887:

BY THE well, where the bullocks go

Silent and blind and slow-

By the field where the young corn dies

In the face of the sultry skies,

They have heard, as the dull Earth hears

The voice of the wind of an hour,

The sound of the Great Queen's voice:

"My God hath given me years,

Hath granted dominion and power:

And I bid you, O Land, rejoice."

And the Ploughman settled the share

More deep in the sun-dried clod:

"Mogul Mahratta, and Mlech from the North,

And White Queen over the Seas-

God raiseth them up and driveth them forth

As the dust of the ploughshare flies in the breeze; 
But the wheat and the cattle are all my care,

And the rest is the will of God." 60

The Ploughman's dismissive comparison of rulers-local and foreignthat come and go like flying dust raised by his ploughshare (hinting at impending spiritual drought?) obscures the fact that such distant powers already had increasingly profound influence on the lives of humans and animals alike throughout India and the South Asian subcontinent. One of the most significant tangible changes for modern India would be brought by the introduction of the tractor. But prior to the tractor would be the railroad, which would provide fast transport of bovine meat to markets. The tractor would make it seem that there was no need for the live ("silent and blind and slow") bullock on the farm. Even less was bullocks' labor missed when, in the early 1960s, the "Green Revolution" took hold in North Indian agriculture. Nor with the impressively increased crop yields did it seem to matter that chemical fertilizers, pesticides, and overirrigation would bring destruction of beneficial insects, soil degradation, and loss of biodiversity. ${ }^{61}$

We may recall from Chapter 3 how in the late 1960s and early 1970s (around the same time that the Green Revolution was expanding in northern India) Swami Prabhupāda began to inspire some of his followers to establish farm communities with cow care in Western countries, where agriculture should be conducted without depending on tractors. Prabhupāda was particularly concerned that bovine bulls be cared for, and integral to caring for bulls would be training them for draught work:

The Europeans have invented tractors, and the bull is a problem. Therefore [bulls] must be sent to the slaughterhouse. So, we cannot create that problem

\footnotetext{
${ }^{60} \mathrm{http}: / /$ www.kiplingsociety.co.uk/poems_whathepeople.htm (accessed 20 May 2018), the first and final of five strophes. "Mlech" refers to mleccha (Sanskrit), essentially "barbarian"-uncultured foreigner.

${ }^{61}$ As an example of tractor use, the number of tractors in Punjab state rose from 10,646 in 1962-1965 to 234,006 in 1990-1993. Fertilizer (NPK) increased in the same two periods from 30,060 tonnes to 1212,570 tonnes (Human Development Report 2004, Punjab, pp. 17-20).
} 
[at our farm projects]. How the bull should be utilized? They should be used for transport, and ploughing. ${ }^{62}$

The connection Prabhupāda makes between the development and use of farm machinery and the resultant replacement of draught animals and hence their slaughter points again to the issue of industrialization and globalization as these have affected the human-bovine (and, more broadly, the human-nonhuman animal) relationship in India. But what is to be also noted here is that globalization's reach in India had additionally a sort of inverse effect, in that Hindu cow care practice has begun to find place outside India, in countries worldwide. Significantly, this practice outside India includes efforts to engage oxen in agriculture-related activities. In Chapter 6, we will look at current Western cow care practices; but first, in relation to experiences of oxen training and engagement, we can view briefly one ISKCON project in India, the Govardhan Eco Village (GEV) in northern Maharashtra, begun in 2003.

Govardhan Eco Village is situated some 100 kilometers north of Mumbai, in the foothills of the Sahyadri mountains. The project's 110-acre area is surrounded by small-holding indigenous (adivasi) farming families which GEV has been endeavoring to help overcome considerable economic and social challenges. GEV also functions as a retreat and conference center that caters largely to visitors from greater Mumbai and Ahmedabad. Moreover, it hosts yoga groups from the United States and visiting non-Indian Vaishnava Hindus from around the world. The project includes a cow care program, with currently some 104 bovines of the Gir and Tharparkar breeds (52 each of males and females, including 12 calves; 12 cows give milk at this writing). The GEV goshala has a specific educational function, namely to show visitors the virtues and spiritual rewards of cow care, while also showing the practicality of cow care, including the training and engagement of oxen.

The first ethical issue related to bulls and oxen is the matter of castration-the operation by which bulls become oxen, which is to say bovine eunuchs. The consensus at GEV is that it is an unavoidable, even if violent,

\footnotetext{
${ }^{62}$ Prabhupāda 2017, Vedabase: Room Conversation, December 10, 1976, Hyderabad. Quoted in Cow Protection-Book 1, ISKCON Ministry of Cow Protection and Agriculture, n.d., p. 38.
} 
action if the bulls born into the community are to be positively cared for and engaged in labor that contributes to the community. ${ }^{63}$ The castration process involves anaesthetization and is done by a veterinarian. If done properly, there is moderate, or no pain experienced. ${ }^{64}$ Prahlada Bhakta, a former GEV goshala manager, explains:

Here [at GEV] the veterinarian comes, the bull is laid down, the veterinarian gives an injection to make him semi-conscious, then he presses that nerve; then [the bull] comes back to consciousness and he is normal again. It is like that. So, it is done with minimum possible violence, I believe.

Present-day Vaishnava Hindus tend to feel ambivalent about bull castration. At Care For Cows in Vrindavan, some uncastrated bulls are kept on nearby land owned by a sadhu who stipulates that they are not to be castrated if they are to remain with him. Other bulls living at the Care for Cows' main facility are generally castrated, since they could otherwise not be sheltered in such proximity to the cows, as the limited space demands. As the Care For Cows manager told me, the founder, the late Kurma Rupa Das, had once commented in this regard, "We must be cruel in order to

${ }^{63}$ Cow Protection-Book 1 (n.d.), the official manual for ISKCON cow care, states the following regarding bull castration: "Recommended: (1) Bull calves of European Taurean breeds should be castrated at 6 months to a year. Indian Zebu breeds should be castrated at 1 year to 2 years. (2) The method of castration should be by emasculation, specifically using the tool bordezio (bloodless castration) performed by a veterinarian, or experienced professional. Not Allowed: (1) Banding (using rubber bands around the testicles until they drop off). (2) Performing acceptable methods of castration by inexperienced cowherd." According to one standard Dharmashastra text, when apaddharma is applicable (irregular circumstances demanding adjustments to regular rules of dharma) if a brahmin takes up agriculture, using bulls for ploughing, they must be uncastrated (Bowles 2018, p. 249).

${ }^{64}$ In January 2015, the Indian Department of Animal Husbandry, Dairying and Fisheries (DADF) issued a circular that "cattle must be given anesthetics prior to castration." That this was announced with approval by PETA India indicates the organization's approval of the general practice of castrating bulls to enable engagement of oxen in labor. https://www.petaindia.com/media/takingpain-cattle-castration-among-animal-welfare-reforms-now-required-india/ (accessed 29 November 2018). According to Maneka Gandhi, the best, most humane method of castration is "immunocastration": injections given every six months, which reduce a bullock's testosterone production. ("Animal Cruelty and Ignorance," at https://www.peopleforanimalsindia.org [accessed 9 February 2019]). 
be kind." ${ }^{\prime \prime}$ That is, in order to be able to shelter the rescued bulls, it was seen to be necessary for them to undergo this quick operation and thus deprive them of reproductive power. ${ }^{66}$ On the other hand, it is reported that ISKCON's nearby Krishna Balaram Goshala in Vrindavan routinely engages uncastrated bulls in work (Dasa 1998, p. 71).

At GEV, engagement of oxen in work has been a priority of the project. But oxen training and engagement has been a learning process for the cow carers as much as for the oxen. In the early days of GEV, the oxen's noses were pierced so that they would be controlled with a rope through the nose, as is widely practiced throughout Asia. ${ }^{67}$ Then, in 2011, the American Vaishnava, Radhanath Swami, the founder and spiritual leader of the community, requested the goshala managers to try to engage the oxen without the nose ropes. Initially, the men were skeptical. Prahlada Bhakta Das recalls,

Radhanath Swami told us, "In Vrindavan we just walk by the bulls [in the streets] and they don't do anything [to disturb us], so why do we need to pierce [our oxen's] noses?" I said to him, "That is how it is done traditionally, and I think there is example in the Bhagavatam [the Bhagavata Purana] telling that just as the bulls are forced to move by a rope through the nose, so everyone is forced by the 'ropes' of maya [illusion] or destiny." 68

\footnotetext{
${ }^{65}$ One interesting exception at CFC was the bull named "Baba," for whom Kurma Rupa devised a "chastity belt"! (CFC Newsletter, February 2006). I was informed by a CFC interviewee that actually the device fails to serve its function.

${ }^{66}$ Further regarding bull castration, Hindu sacred texts appear to be not univocal, similar to equivocal injunctions related to meat consumption we saw in Chapter 3. On one side, there are references (in the Shatapatha Brahmana, e.g., 2.2.3.28 and Taittiriya Samhita 1.8.17.1) indicating that an ox was to be given to a ritual priest as a sacrificial fee. But in Padma Purana, Bhumi-khanda 67.88, we find, "Those men who, being most sinful, strike the scrotum of bulls (i.e., castrate them) and they who harm cows' calves are residents of a great (i.e., very painful) hell." My thanks to Brijabhasi Das for providing these references.

${ }^{67}$ The recently produced manual for Indian goshalas (Khanna et al. 2017, pp. 70-71) speaks approvingly of bull castration and nose-ring insertion, noting that both should be done at one year of age. It also speaks approvingly of de-horning (within a few days of birth). This is strange, considering that one of manual's editors, Maneka Gandhi, writes strongly against these practices in her article "Animal Cruelty and Ignorance" https://www.peopleforanimalsindia.org (accessed 7 February 2019).

${ }^{68} \mathrm{BhP}$ 6.3.12: Yama, the lord of death, compares the cosmic creation to a bull. "The world is controlled by Vishnu as [a bull is] controlled by a rope in its nose." Several more verses in the text employ the same analogy.
} 
Radhanath Swami said, "Yes, but if it is possible [to engage the oxen in work without nose ropes], why not do it?" 69

By all reports (and my own observation), the experiment has proven successful, and now none of the oxen at GEV have nose ropes; rather, they work with a halter, without nose rope or ring. ${ }^{70}$ However, as Jagannath Kripa Das, the present GEV goshala manager, points out, the goshala's concomitant challenge is to have enough engagement for the several resident oxen. Some ploughing and load-carrying (mainly transporting their fodder and dung) engage two pairs of oxen in a day, following a rotating system to keep all the oxen trained. Prahlada Bhakta Das observed,

It is not difficult to drive oxen when they are well trained. I have taken them to the village to get fodder for the cows. Taking the cart, putting two oxen, and they are trained, they know the commands.... So, it is not difficult to work with trained oxen, but it is difficult to train them.

Engagement of oxen requires training of those who engage them as well as training of the oxen. Prahlada Bhakta notes the problem of untrained trainers:

There is a particular way to train the oxen, but because someone who does not have the knowledge [how to train them] wants to make them work, the oxen suffer, and you don't get any work done. So that knowledge is essential. We have to somehow train people to train oxen.

As an institution that has several start-up agricultural projects, ISKCON managers are sometimes faced with having inexperienced, if enthusiastic, herders and trainers. To address this problem, Syamasundara Dasa compiled a manual that anticipates this and all other, practical issues related to bovine care. Anticipating inexperienced oxen trainers, he writes,

\footnotetext{
${ }^{69}$ Interview with Prahlada Bhakta Das, 10 December 2017.

${ }^{70}$ Whether oxen can be engaged in work without the control of a nose rope or nose ring can depend on their breed. Gir and Tharparkar are relatively docile breeds in comparison with others. Large Western breeds of oxen need the control afforded by a nose ring, according to Antardvip Das (the oxen manager at the ISKCON-Hungary farm, which we will discuss presently).
} 
At first the oxen will be quite nervous of many things, from putting on the yoke; the feeling of being trapped by it; the tugging on their noses; the closeness of another ox at the other end of the yoke (who may want to butt him); to the pulling of the load, etc. The trainer must be prepared for the oxen to be somewhat unpredictable and for this reason great patience and kindness should be shown towards them. They will undoubtedly make many mistakes at first, so one should be prepared and at the same time, willing to persevere. (Dasa 1998, p. 78)

An ox trainer must show "great patience and kindness" in leading new oxen into the habits they must have to perform the draught activities for which they are well suited. And the best and traditional way for a new ox trainer to learn the art is from an experienced trainer. In the absence of available personal guidance, in our Internet age, one long-experienced trainer, Balabhadra Das (William E. Dove), the founder of ISCOWP (International Society for Cow Protection), who has been training oxen over twenty-seven years, offers videos online in which he demonstrates the process in a step-by-step manner that involves the use of voice commands as the basis of gentle engagement of oxen. ${ }^{71}$ Significantly, Balabhadra emphasizes that the first step in training oxen is making friends with them, which means spending time with them, addressing them by their names, and brushing and stroking them.

All of what has here been described in connection with bull castration, nose ropes or nose rings, and training of or working with oxen might be dismissed by some persons as clear affirmation that Hindu cow care is fraught with violent practices. Conscientious Hindus will acknowledge that there are aspects of cow care that have what some will label "violent" due to infliction of some temporary pain on bulls, and permanent denial of mating capacity. Yet Hindus will insist that, first, the dignity of bulls is not thereby compromised and, in fact, their lives are enhanced and valued more for the service they will give; thus, second, they remain protected and cared for throughout their natural lives-hardly the case for most bulls

\footnotetext{
${ }^{71}$ See, for example, "Training Oxen by Voice Commands." https://www.youtube.com/watch?v= aCJibJ4Axi8 (accessed 29 November 2018). ISCOWP's Web site has several videos: https://iscowp. $\mathrm{org} /$ videos/. Balabhadra's oxen are with halters, not pierced noses. ISCOWP is based in Gainesville, Florida.
} 
that are killed soon after they are born or as soon as they reach "slaughter weight." 72 Further, they would say that one must view the composite practice as a whole-its context in the wider scheme of human living with nonhuman animals and the natural environment, as well as the spirit of those who directly engage with the cows. In my own visits to various goshalas in India, I found a variety of attitudes—some more and some less conducive to a sense that a serious effort to uphold dharmic principles is being observed. Yet in all cases and as a whole, what I saw was an important effort to demonstrate a positive alternative to the killing culture of modern agribusiness in all its pervasive forms of animal abuse and destruction.

\section{Intangible Benefits of Bovine Care and Proximity}

We have discussed bovine products—-milk, dung, urine, and their derivatives — as tangible benefits from bovines. Similarly, labor of male bovinesdrawing a plough or transporting goods and people-is a tangible bovine benefit. Yet as already noted, all these benefits do not add up to make the total sum of why cows are to be cared for, or why cow carers feel that all the challenges of cow care are worth the trouble. Here we will hear expressions of appreciation for cows' intangible, or non-quantifiable, benefits for humans and the environment.

\section{Bovines as Purifying Agents}

At Pathmeda I asked Swami Shri Datta Sharanananda Maharaja, the founder of this massive goshala complex in southwest Rajasthan and longtime India-wide itinerant cow care activist, how he might explain the benefits of lifelong care for cows, especially to persons unfamiliar with the ethos of Hindu cow care. Datta's extensive reply showed a deep conviction in the value of cows to render three sorts of benefit for human beings,

\footnotetext{
${ }^{72}$ Modern meat "production" functions in a globalized context with exacting calculations of "feed efficiency ratios" and the like, with the singular aim of bringing the animals up to the desired weight at which they can most profitably be slaughtered (Smil 2013, pp. 113-175).
} 
namely benefits to health, to prosperity, and to education. A summary of his explanation will be useful to appreciate how a Hindu valuation of cows comprehends several aspects of human well-being. ${ }^{73}$

According to Datta, the general benefit of bovines resides in their power to favorably affect — to purify — natural elements, where "elements" are understood in terms of a classical Hindu analysis of nature. ${ }^{74}$ According to the Bhagavad Gita (7.4), there are eight components ("elements") of gross and subtle matter, referred to as ashtada-prakriti. These eight components of matter, or temporal nature, are earth, water, fire, air, ether (kham), mind (manas), intelligence (buddhi), and ego (ahamkara). Considering that cows are known to favorably affect all these components of nature, Datta elaborates on how each of the three aspects of human well-being come about through human interaction with such favorably affected elements. Thus, maintenance and recovery of human health are based particularly on bovines' power to purify earth, water, and air. Earth, purified by the fertilizing dung of the cow, yields organically fertilized earth's nutrient-vegetation that we consume, contributing to the body's vigor. Water, purified by cow urine (as a disinfectant), contributes to the well-being of human bodily liquids, and air in the proximity of cows, purified by the cows' breath, ensures a healthy pulmonary system. ${ }^{75}$

Swami Datta next identifies properties of cows that help create and sustain prosperity. The main idea is that bovines' presence among humans fosters balance and moderation in human endeavor, specifically by their essential contribution to ritual procedures (yajna) for maintenance of cosmic order. As we discussed earlier, ghee produced from cows' milk, which is offered as oblation in the yajna fires, is understood to purify fire (one

\footnotetext{
${ }^{73}$ Interview with Swami Datta Sharanananda, 4 December 2018. For a similar appreciation of cows' positive effects on humans by Pandurang Shastri Athavale (1920-2003), founder of the Swadhyaya Parivar, see Jain (2011, pp. 39-41).

${ }^{74}$ The notion of "purity" and "purification" and their opposites, pollution and contamination, may signal the brahmanical ethos prevalent in Hindu discourse and, usually quite negatively valenced, in critical discourse about Hinduism. That cows and their high valuation are closely associated with brahmanical ethos seems to affirm this association. For further discussion of purity and pollution in Hindu thought and practice, focusing on bovine products, see Simoons (1974).

${ }^{75}$ Such understanding of cows' purifying powers and resultant human health benefits might be taken as "indigenous knowledge," to be dismissed as such. But several writers have argued strongly that such knowledge needs to be valued and recovered, as an integral feature of recovery from colonialist discourses of domination. See Henry (2015).
} 
of the eight constituents of temporal nature). Moreover, even the lowing sound of cows purifies what is understood to be the basic medium of sound, namely "ether," or sky (kham; akasha).

A lack of regard for cows is directly related to the predominance of greed and avarice that characterize present-day economic enterpriseepitomized by fossil fuel extraction with the consequent environmental imbalances arising from its barely restricted use, including chemical fertilizer that poisons the earth. In terms of traditional Hindu analysis of cosmic dynamics called Samkhya (discussed in the Bhagavad Gita), the predominating present-day economic culture is permeated with nature's quality of passion (rajo-guna), the modality characterized by short-sighted and self-centered pursuit of ambition. In contrast, an economy rooted in due regard for cows such that they are cared for throughout their natural lives is sustainable and hence stable, thus upholding the sort of human order of prosperity characterized by the quality of illumination (sattva-guna). ${ }^{76}$ In this latter case, greed and avarice can be subdued by cows' purifying-or stabilizing-effect on the mind, such that the human being's tendency to exercise oppressive control and exploitation of other beings and the environment is restrained. This effect complements cows' sobering effect on the subtlest of the eight components of nature, the "ego" (ahamkara) which is understood to be the sense of individuality that, in its negative aspect, is experienced as alienation, the locus of all human destructive impulses.

The third practical benefit of cows, according to Swami Datta, is their role in fostering the best conditions for human education. This aspect of human benefit arises from a dual function of giving and receiving in relation to cows. There are direct and indirect gifts of the cow that humans are able to receive. Milk and its derivatives, as well as dung and urine, are cows' direct gifts, as we have already discussed; and indirect gifts are the produce from agricultural processes in which cows are involved. That is

\footnotetext{
76We will discuss the Samkhya system of thought further in Chapter 6. Suffice to note here that it may be roughly compared to the Chinese Taoist notion of yin/yang, though in the Indic system there are three, rather than two, constituents, and these three are generally graded in preference from tamas (darkness, ignorance) to rajas (energy, passion) up to sattva (illumination, true-being) in terms of conduciveness to attain spiritual fulfillment.
} 
to say, cows benefit education by building a character and value system of people and community engaged in their care, as integral to agricultural life.

All of these benefits foster illuminated intelligence (sattvika-buddhi) when received gratefully. But such benefits can only come when the cows that bestow these gifts are given proper and affectionate care in return. Such care includes providing all the necessities of maintaining them in a healthy and peaceful condition, free from anxiety. Moreover, Swami Datta emphasizes, to properly reciprocate with cows for their gifts that benefit the world, they are to be shown special regard through formal practices of veneration (upasana), the appropriate spirit of which is to be nourished by regular cultivation of faith (shraddha) that comes from hearing sacred texts-including those that extol cows - as well as hearing from and assisting persons dedicated to these texts, the sadhus and learned brahmins.

\section{Learning Lessons from Cows}

In thinking about intangible benefits of cow care, tangible challenges cannot be ignored. On one side, there are considerations of cow product values, including both physical products with their economic valuation and the value of intangibles, such as the sense of well-being experienced when cows are properly cared for. And still there are the costs that invariably come with proper care of cows (including costs of land, buildings, fodder, and medical costs; hired labor costs, including their needs (including proper training); and the costs for any equipment such as for milk processing). ${ }^{77}$ For a private person who cannot expect the kind of donor support that institutional goshalas typically receive, economics becomes a major issue. The commitment required for maintaining cows in a healthy and happy condition throughout their natural lives is certainly high, and some who feel that they would otherwise want to care for cows may conclude that it is more of a commitment than they could realistically make. As we have seen, for many, the only commitment they can make for cow care is to give

\footnotetext{
${ }^{77}$ Whether or not there is hired labor, whoever takes part in the cow care activities must also be nicely maintained, with all the expenses this will involve.
} 
regular donations to a goshala or similar institution. And yet there are also individuals for whom the personal rewards of direct cow care are worth all the trouble and expense. Of this sort of person here is one vignette. Aside from the theme of intangible bovine values, this vignette affords us a look into a very small-scale project, quite the opposite of Pathmeda with its thousands of cows.

Janmastami Das, an Indian native from a several-generations family of Krishna-bhaktas, cares for his 105 bovines on his three-acre farm amidst a jungle, just off the Mumbai-Ahmedabad highway a few kilometers north of Mumbai. Recalling the multiple hardships that he and his wife and son endured in establishing their project, Janmastami admits that at one time he wanted to give up and return to his former life in the city. But his wife said to him, "You can go if you like; I will stay here with the cows." Inspired by his wife's resolve, Janmastami mustered his own determination, and now, since several years, he sees his cows as his instructors, teaching him essential lessons in the culture of bhakti.

One lesson he reports to me involves the Vaishnava tradition's exhortation to cultivate humility. "By regarding oneself as lower than the straw on the ground ... one can always glorify the Lord, chanting his names."78 Janmastami explains,

It is one thing to think oneself lower than the straw, and it is quite another thing to realize it. One day I was washing down the cowshed, hosing out the straw. There was one small piece of straw that just wouldn't move, however much I blasted it with high water pressure. Then it dawned on me: the cows, pressing the straw down repeatedly with their hooves, are showing me that if I would become actually humble like this straw, then the heavy forces of lust, anger, greed, envy, and so on, cannot overwhelm me.

Janmastami ties this lesson in humility to a second lesson he credits the cows with helping him to understand:

\footnotetext{
${ }^{78}$ This is from stanza 3 of the 8-stanza Shikshashtakam attributed to Sri Chaitanya (1486-1533): "By regarding oneself as lower than the straw, by being tolerant like a tree, by expecting no honor (for oneself) and offering honor to all others, one can always glorify the Lord, chanting his names" (Prabhupāda 2005 [1974], p. 1442; Chaitanya Charitamrita, Antya 20.21, my translation).
} 
We should remember that Krishna is known as Govinda, a name that reminds us of his relationship to cows. We daily chant this name in the mantra that also includes the word svaha which—so we usually thinkmeans "oblation," as one would pronounce when offering ghee in a ritual fire. In a fire ritual (yajna), we keep many things with us, we are not really giving up everything. But Govinda - the Lord of the cows — teaches us how to give everything and take full refuge in him.

Janmastami insists that taking full refuge in Krishna as Govinda is essential for one to be able to take proper care of cows. Recalling Keshi's comment on how everything necessary for cow care (at Care For Cows) is made available by the grace of Krishna's consort Radharani, we may also appreciate Janmastami's observation that if one takes refuge in Govinda, "Mother cow gives everything I need. I'm seeing now that I'm the richest person: I am able to do seva [service] to my parents, my guru, Krishna, and mother cow-four types of seva, so I am the richest person in the world."79

The expression go-seva was often used in conversations I held with cow carers and cow activists; indeed, a preferred term for themselves is go-sevak-one who serves cows. The idea of serving cows, as opposed to being served by them or being the beneficiary of cows' products, is a common theme among these Hindus. From this perspective, cow care may be regarded as an ethics of service, whereby "relational humility" (Dalmiya 2016) fructifies with a sense of inner and outer abundance.

\section{"Keeping Cows, You Keep Your Sanity"}

Another striking example of a dedicated single-family cow care project in India is that of Hrimati Dasi, a German native who lives since 1996 near the Hooghly River, a Ganges tributary, 130 kilometers upstream from Kolkata in West Bengal. As a follower of Swami Prabhupāda, for most of the twenty-two years she has lived in this area she has kept cows. Presently, she has ten-eight cows, one bull and one ox. Hrimati gives credit to the cows for her well-being - for maintaining her "sanity," as she puts itwhile also expressing concern about future conditions for herself and the

${ }^{79}$ Interview with Janmastami Das, 28 November 2017. 
cows. It was the milk of her first cow that, she says, sustained her and her four children when, for a time, she was without income and without the help of her husband, from whom she had separated.

[My children and I] were living on milk, spinach, and donations of rice; the cow was giving one and a half liters' milk. Then we had a bull, and one boy came and gave a donation to make a bullock cart. After a few days, within a week, the cow was giving five liters per day. We were drinking two liters [of milk] and I could sell three liters.

Supplementing her minimal income from milk with the sale of homemade cloth dolls - forms of Krishna and his various associates-Hrimati gradually learned by trial and error how to care for her cows. She learned a key lesson from working with her first cow, Vishnupriya, a mixed reddish Sahiwal breed she had received from the nearby goshala of ISKCON, Mayapur, in the year 2000. As one of the several dozen cows in that goshala, Vishnupriya had been receiving minimal attention. Hrimati says that thereafter, under her direct care, the marked increase in attention inspired Vishnupriya to more-than-triple her daily milk yield.

Giving ample attention to individual cows is good and important for cow carers, but of course cows also need substantial daily nourishment, a constant challenge for Hrimati with the one acre of her neighbor's land she is allowed to use for growing fodder. Twenty-five to thirty kilograms of green grass fodder per cow is required, plus one and a half kilograms of grain mixture (including flax seeds, soaked chickpeas, a mineral mixture, and wheat bran or crushed maze). Keeping the cows well fed keeps them stress-free, minimizing the chance of becoming diseased. Hrimati now hires two men to assist her in feeding the cows (three times a day, plus two times a day they are led out for grazing), but their wages, plus the cost of fodder that is supplementary to what she can grow, are becoming a strain. All the children have grown up and left home, and Hrimati's own health issues give her further worries.

Yet despite the challenges, this hardy woman from the West, who now speaks fluent Bengali, considers her cows to be her family, in a place where she finds a cultural climate in which she sees at least some respect for cows. 
For her, such respect and care for cows are the very substance and foundation for what she calls "living simply and depending on Krishna," a principle drawn from a motto often expressed by her guru, Swami Prabhupāda, as "plain living and high thinking." grounded in a sense of dependence on divine grace is, Hrimati feels, seriously compromised by high reliance on modern technology. She expresses concern about the overly convenience-dependent lifestyle of present-day Vaishnavas (both Indian and non-Indian), those who should be more closely embodying the ideal they propound:

Prabhupada said [that Vaishnavas, devotees of Krishna, must learn] to depend on Krishna. But are we actually depending on Krishna? What are we doing different from the karmis [persons absorbed in self-centered activities], actually? ${ }^{81}$

On several occasions, Swami Prabhupāda assured his followers that if they would live on the land and take care of cows, all their needs would be fulfilled. ${ }^{82}$ Hrimati Dasi, although continually challenged by material conditions, goes on caring for her cows, bolstered by faith in her guru's words and in Krishna.

\section{Go-seva and Bhakti}

Indeed, in the practice of Krishna-bhakti, according to the sacred texts, the initial step on this path is to have at least a minimal sense of faith (shraddha) that the practice of bhakti and the object of bhakti (Krishna) are true and real. Such initial faith is then nourished by regular practice,

\footnotetext{
${ }^{80}$ For example, in a letter to his student Hayagriva Das (June 1968), referring to a newly acquired farm in West Virginia that would become New Vrindavan, Swami Prabhupāda wrote: "It may be an ideal village where the residents will have plain living and high thinking. For plain living we must have sufficient land for raising crops and pasturing grounds for the cows. If there is sufficient grains and production of milk, then the whole economic problem is solved" (Prabhupāda 2017, Vedabase: Letter to Hayagriva-Montreal 14 June, 1968).

${ }^{81}$ Interview with Hrimati Devi, Mayapur, West Bengal, 22 January 2018.

${ }^{82}$ Swami Prabhupāda writes in his Bhagavata Purana commentary (to v. 9.15.25): “The whole world must learn from Krṣna how to live happily without scarcity simply by producing food grains (annād bhavanti bhütāni [Bhagavad-gita 3.14]) and giving protection to the cows (go-raksya)."
} 
essential to which is menial service for one's preceptor, the guru. We may recall the story of the student of the guru in the Upanishad (Chapter 2) caring for the guru's cows. This same tradition continues today.

One Vrindavan sadhu, Satya Narayan Das Baba, remembers how his own guru, the late Shri Haridas Shastri, a highly learned Sanskrit sacred text scholar and author, would, despite study and teaching duties, spend most of his day with the cows in his goshala. He would say to his Vaishnava theology students,

We are worshipers of Krishna, who is Gopal [the divine cowherd], and Krishna himself took personally care of the cows. Krishna has the abhiman [the mood] of a cowherd boy. That is his identity, and if we want to be with him, then we have to get into that mood.... If you attain perfection and go to [the eternal atemporal realm] Vrindavan, what will you be doing there? If you are a cowherd boy [in your eternal, spiritual identity] you will be taking care of cows; if you are a gopi [cowherdess, as your eternal identity] you will still be taking care of the cows. So, we better start practicing, doing it here [in this world]!

The "practice" being referred to in this exhortation is a regimen of devotional activities (sadhana-bhakti) that dedicated Krishna devotees, bhaktas, daily perform. This practice is designed to maximize one's attention to the service and remembrance of Krishna as both the supreme person, or God (bhagavan), and the absolute reality (satyam param). Such practice, rooted in teachings of the Bhagavad Gita and Bhagavata Purana, aims at constantly endeavoring to absorb one's consciousness in Krishna in the course of one's life. Thus, one can look forward to attaining Krishna's eternal realm, there to be ever freed from the repetition of death and rebirth and to participate perpetually in Krishna's ever-new "pastimes," or divine play (lila). ${ }^{83}$ As such practice necessarily involves activity with

\footnotetext{
${ }^{83}$ The details of how sadhana-bhakti is to be practiced are extensively elaborated in the two texts mentioned, as well as in commentaries to these and in later works composed by practitionerpreceptors. The Bhagavad-gita provides basic instructions for the practice of devotional, Krishnadirected activities, indicating that the result of successful practice is to attain, after death, Krishna's "state of being; of this there is no doubt" (Bhagavad-gita 8.5; Goswami 2015 trans.). For a study of bhakti practices in the Vaishnava Hindu tradition (including meditation on Krishna as he is situated in Vraja with the cows), see Holdrege (2015, especially Chapters 5 and 6).
} 
one's physical body and mind, and since care for cows necessarily involves the practitioner with the world and bodily necessities, this practice is seen as an ideal way to position oneself in this world so as to connect with the atemporal realm to which the atemporal self (atman) permanently belongs.

Clearly, such an understanding of cow care, as a Vaishnava Hindu spiritual practice, partakes in what today is a quite rarefied and rarely seen sphere of human cultural values. ${ }^{84}$ Yet it is arguably from such an ideational locus of bhakti practice that we can best appreciate what it is that drives Hindu cow care that is connected with the practice of Krishna-bhakti. Put simply, for Krishna-bhaktas, by caring for cows they regard as belonging to Krishna, the cows reciprocate in such ways that the bhaktas' devotion to Krishna is enriched and strengthened. ${ }^{85}$

\section{Ritual Bovine Veneration: Creating and Affirming Community}

In Chapter 2, we encountered a Sanskrit ritual manual, the Gavārcanaprayoga, "Procedure for the Worship of Cows," and we noted that it includes rituals both for the benefit of cows and benefit for humans from the cows, including a mantra for protection by cows. What is not

\footnotetext{
${ }^{84}$ According to the Pathmeda goshala organization, they have succeeded in helping "thousands" of people to become free from addictions by doing go-seva, service to cows (Dattasharanananda 2017, back cover). Whatever truth there is to the claim, it points to a general notion I heard several times from cow carers - that cows have a calming and "purifying" effect on the mind when one engages in their service.

${ }^{85}$ One striking story of dedication to the service of Krishna's cows was told to me by Raju, a resident of Govardhan (in the area of Vraja) and cowherd for the thirty cows of one Ukrainian resident, Arca Murti Dasi. Raju suffered an accident while servicing an electrical inverter when the device's liquid acid exploded onto his body and face, completely blinding him. While being cared for by his family at home after returning from the hospital (where he had been informed that he would never see again), at night he dreamt that Surabhi, the senior cow of the herd he had been taking care of, appeared and spoke to him, complaining of his neglect. In the dream, he explained to her what had happened to him, saying, "If you bless me with eyesight, I can again care for you." Within a few days his eyesight was fully restored, a recovery that he fully credits this cow for giving him, inspiring him to vow that he would always, for the rest of his life, serve Krishna's cows (interview with Arca Murti and Raju, 14 February 2019).
} 
stated explicitly in this manual, but is nonetheless significant, is that cows create community, in particular by way of ritual performance dedicated to cows.

Among nine types of activities practiced and promoted in relation to cows at the Gaudham Mahatirtha Anandvan goshala complex at Pathmeda, three activities stress the importance given to ritual practices in relation to cows. It bears emphasizing that these practices are understood to be essential for affirming the proper place and function of human beings in relation to the cosmic order in the broadest sense. ${ }^{86}$ This is the order expressed by the term dharma, which, in turn, is upheld when cows are served and, on occasion, formally honored in a hospitality ritual known as puja. ${ }^{87}$ Important to note is that these rituals - much simplified today from the ancient rituals indicated in Chapters 2 and 3-are most often public events that constitute focal points of spiritual retreats attended by guests - typically urban people who are regular donors and who identify with the mission of the project. ${ }^{88}$ Such a ritual of go-puja-honoring of cows - was underway when I visited there in late 2017. Each of some fifty guests was simultaneously presenting the prescribed auspicious items to a respective cow standing opposite them, while a priest guided them through the actions and chanted the appropriate mantras, all in the duration of well over an hour. As one might expect, the venerated cows showed little interest in the proceedings, except toward the end as they were offered delectable snacks! For us to note is that the event brought the guests together in a common ritual activity, in effect creating a temporary community that had as its identity the veneration of bovines, thereby transforming the cows, for a time, into a sort of collective "bovinity," or bovine-divinity.

\footnotetext{
${ }^{86}$ These three rituals refer to acts that acknowledge three out of five congenital debts. See Chapter 5 , "Dharma as settled duty" and Chapter 5 footnote 6 for an explanation. Sattva-puja responds to the debt to divinities; srishthi-yajna responds to the debt to ancestors; and svadhyaya responds to the debt to the sages (rishis). The ritual veneration of cows is, according to the tradition followed by Pathmeda, integral to the complex of these rites.

${ }^{87}$ For a survey of puja theory and practice in Hindu traditions, see Valpey (2010).

${ }^{88}$ At the Pathmeda event I observed in 2017, some 200 guests had assembled, of whom around 50 participated in the go-puja. There prevailed a lighthearted atmosphere of jovial camaradarie among the guests, blended with a sense of earnestness in showing reverence to the cows, particularly in the presence of the highly respected Swami Datta Sharanananda.
} 
Up to now, I have a few times invoked the term "bovinity" to call attention to Hindu regard for bovines as sharing in and embodying divinity in animal form. As we look at the ritual dimension of Hindu cow care, we do well to pause and look more closely at the theological reasoning in this notion. I draw again from Swami Datta Sharanananda, quoting from his preface to Gavārcanaprayoga, the previously mentioned ritual manual for venerating cows. Swami Datta begins by explaining why specifically cows are venerable.

In every hair of the universal mother, go-mata, reside the countless divinities. By venerating go-mata, the celestials, sages, ancestors, and all beingsmoving and non-moving, conscious and non-conscious - are satisfied. Gomata alone in the form of earth shelters all moving and non-moving beings in her lap, and thus in both forms [as cow and as earth] she provides them nourishment. ... If there is just one cow in the home that is served daily, it is as if all the celestials, sages, ancestors, Vedas, sacred rites, and so on, being attended, are all kept satisfied. By using the substances from cows for sacred rites (yajna) and so on, the basis of protection for bovines and their servants is at hand.

Swami Datta goes on to explain that of five major divinities, four of which are male in gender, the one feminine Maha-Shakti is most important, as all benefits coming from the male divinities' worship come about only by her grace. He then explains that there are varieties of veneration, depending on the motivation of the worshiper. The highest form, which is very rare, is extremely secret (gopaniya), bringing benefit for all beings. Further, there are two types of worship, depending on the object of worship-either a physical form made of earth (or earth-based, that is, stone or metal) or else a living form. Of the latter, the only form that is authorized (svikrita) is that of Shri Surabhi Go-Mata-mother cow, who is the blessed divine Surabhi.

The identification of cows in general with the divine Surabhi (including males-one hears the term go-vamsh, an inclusive term for male and female cows) locates cows as representative of the divine feminine which, in turn, is identified with the earth as the source of sustenance for all beings and, more abstractly, with prakriti, nature as a whole. Thus, cows manifest the divine-and-natural feminine, over against the divine-and-human male 
principle, purusha, which is present in all humans (but in fact in all living beings, according to Samkhya philosophy) whether the body is male or female. According to Swami Datta, the rare persons who comprehend these identities will naturally venerate cows, knowing that by doing so all of nature will be venerated and all beings (purushas), being supported and sheltered by venerated nature, will be satisfied and peaceful. The rarity of this understanding, Swami Datta implies, is due to the fact that the vast majority of people seek satisfaction for themselves and their immediate circle of friends and family. Such persons are likely to venerate predominant male divinities_-Brahma, Shiva, Vishnu, or Ganesh—thus missing the opportunity to be instrumental in benefiting the whole world through veneration of Surabhi.

There is a sense, then, that cow veneration serves to affirm and celebrate the existence of an all-inclusive community of living beings. As ritual action, cow veneration as conceived here partakes of the broader cosmic cycle of which Krishna speaks in the Bhagavad Gita, centered on the practice of sacrificial rites (yajna). One may regard puja as a simplified and democratized form of yajna, whereby humans act as agents for cosmic regeneration by performing ritual offerings to invisible divinities. In the case of cow veneration, cows are very much visible and alive, their tangible presence offsetting the intangibles they represent.

In contrast to the go-puja at Pathmeda just described, which created a temporary sense of community among the congregants, here is a brief description of a similar, but much smaller-scale cow veneration rite observed at GEV. The point of contrast is not just the scale, but the fact that this is a residential community. Prahlad Bhakta tells how, through one particularly inspiring occasion of celebration involving veneration of the cows, he came to realize just how uplifting such a community can be when serving the cows together:

To conclude the Govardhan Puja festival, we brought two cows and an old ox from the goshala. We decorated them with colored cloth on their backs, flower garlands, and sindhur [red powder] hand prints on their sides. While everyone gathered around and sang kirtan, the brahmacharis [student monks] were offering the standard sixteen items [to the bovines], and 
I recited the appropriate Sanskrit mantras, reading from a book I had, containing directions for go-puja. ${ }^{89}$ We felt so nice; after the festival everyone was commenting, "We feel so happy in our hearts right now. It is such a joyful environment, we can feel the change."

From the perspective of Hindu cow care tradition, the sense of a "joyful environment" could be explained as affirmation that the proper relationship between humans and animals is being manifested, whereby humans show (day by day, and occasionally through ritual) their gratitude to the animals for their gifts; and that such joyfulness is indicative that cosmic order, dharma, is being upheld.

As a summary of the varieties of ways that cows are seen as benefiting the human world, we may recall the Rigveda verse from Chapter 2 (RV 6.28.6):

You fatten even the thin man, o cows. You make even one without beauty to have a lovely face. You make the house blessed, o you of blessed speech. Your vigor is declared loftily in the assemblies.

Cows can bring well-being to all, and significantly, they are represented here as possessing "blessed speech," suggesting that language is somehow involved in their having beneficent power. Cows "speak" to humans in such ways that humans feel compelled to respond-to care-about and for them.

\section{Concluding Reflections}

This chapter began with accounts of urban cows in India as victims of modernization and industrialization and of how organizations and individuals respond with cow shelters, efforts at attentive Care For Cows' welfare, and

\footnotetext{
${ }^{89}$ As described in Chapter 2, Krishna lifts Mount Govardhan in defiance of Indra. Krishna had advised the Vrindavan residents to offer a feast to Govardhan rather than to Indra, and to venerate the cows. This episode is celebrated annually by Vaishnava Hindus in autumn. Kirtan is typically congregational singing of Krishna's names, in call-and-response fashion. Sixteen items of worship include waving of ghee-soaked cotton wick lamps before the cows, and giving them pleasing food, such as bananas and jaggery.
} 
various attempts to raise public awareness and involvement. As cows are left to scavenge human refuse, they ingest "foreign" matter, ${ }^{90}$ themselves having become literal outcasts as if they had been made members of social "outcaste" groups. Yet at the same time, paradoxically, these same cows-in particular deshi (indigenous breed) cows-are revered as go-mata (or gaumata) — mother cow_ — and as such, many Hindus sympathetic to Hindu nationalist ideology identify cows (again, in particular those of indigenous breeds) metonymically with the land of India as sacred land. With such identifications, cows' bodies have become the sites of multiple battles in India. ${ }^{91}$ The contours of these battles may be conceived variously. In a broad sense, for some Hindus, they take on the bigger-than-life dimension of a civilizational struggle — of a quickly degrading land struggling to recover what is regarded as pristine tradition. On the well-intentioned side of this narrative, there are people — not only Hindus - who want to see that cows are protected in a protective culture that resonates with the sense of dignity for all beings implicit in the notion of sanatana-dharma, enduring cosmic order. But on the dark side of what appears to be the same narrative is an increase-rather than a decrease-in violence, when "cow vigilantes" or Islamophobic Hindu villagers engage in lynching of (typically Muslim) cow butchers or beef eaters. Thus, the cow, "a poem of pity," as we have seen M. K. Gandhi referred to them (Gandhi 1999, vol. 24, p. 373), continues to be highly politicized in India, as we saw in the previous chapter. Simultaneously, they are objects of benumbed indifference at worse or of tolerance at best, as cows roam cities and towns, causing the occasional traffic jam if not getting hit or killed by reckless drivers.

Here our concern has been with the connections between the routine practices of cow care, the economics of such care, engagement with cow products, and what may be called a "missionizing orientation" to these practices, tethered to an ideology of modern Hindu thought, with its wide variety of inflections. Bovine utility rates high in the calculus of cow

\footnotetext{
${ }^{90}$ The play on the word "foreign" is intentional: The inorganic products of industry ingested by cows can be seen as having their origin in the globalized industrial complex of which India has become increasingly a part (since at least the eighteenth century).

${ }^{91}$ In the West, cows have also been the object of intense struggle over ownership, grazing rights, and questions of disease causes and proliferation. See Carlson (2002).
} 
care values that range from physical, economic, and ritual value of living bovine products - milk, dung, urine, and traction - to intangibles such as purity and social upliftment. And all these are tied to, or in tension with, ethical values, especially nonviolence (ahimsa), animal welfare, animal rights, and human rights. By focusing on cow care practices especially at cow shelters (goshalas), this chapter serves to locate attempts to bring these values into balance in specific sites of human organization set apart from the sites of agribusiness and dairy industry. I have purposefully dwelt on specifics of living bovine utility, since all of these-tangible and intangible goods - are greatly emphasized by most if not all Hindu cow carers and activists.

"To bring these values into balance" is a way of expressing the notion of dharma, which I have mentioned a few times in this and the previous chapters. Here we can anticipate a point to be treated further in the next chapter: In classical Sanskrit texts such as the Mahabharata, dharma is sometimes designated as one of four "human aims" (purusha arthas), and the other three being satisfaction of desire (kama); pursuit of wealth (artha); and pursuit of freedom (moksha). The point to note here is simply that cow care as the pursuit of right action (dharma), when linked to valuing of living bovine tangible utility, can be viewed as ethics oriented toward the pursuit of desire and wealth. When linked with bovine intangible utility, dharma can be seen as ethics oriented toward the pursuit of freedom. Yet even if dharma serves to balance these pursuits by facilitating all of them in harmony with higher order, these aims remain in the realm of selfish interest (rooted, according to Samkhya thought, in ahamkara or "ego") and hence are the stuff of anthropocentrism, or the sense that all values are rooted in human interests. "Anthropocentrism" is another name for human alienation from nature. Thus, according to Vaishnavas, cow care that is divorced from the devotional principle, or the bhakti paradigm, even if practiced for the sake of dharma, is sure to perpetuate a sense of alienation. As a result, the principle of dharma that is so highly valued, nonviolence, remains imperfectly achieved. This is why I have selected each of the goshala projects briefly examined in this chapter. What they all have in common is, in my perception, a strong bhakti ethos, such that there prevails a sense that the cows are cared for 
as vulnerable, and very wonderful, creatures_beings in their own right, rather than objects of ownership (Johnson 2012, pp. 100-122).

This and the previous chapters serve as background for Chapter 5. This background is essential to appreciate the literary, historical, and current living context in which one major sphere of Hindu animal ethics concern - that of cows- has unfolded. In the next chapter, we step back for a more theoretical and wide-angle view of Hindu animal ethics, keeping in mind the specific concern of cow care. Then, in Chapter 6, we refocus on bovines to explore possible futures for their care.

\section{References}

Ahimsa Milk Dairy. n.d. https://www.ahimsamilk.org/. Accessed 30 November 2018.

Banta, Jim E., J. W. Lee, G. Hodgkin, Z. Yi, A. Fanica, and J. Sabate. 2018. The Global Influence of the Seventh-Day Adventists on Diet. Religions 9(251). https://doi.org/10.3390/rel9090251.

Baviskar, Amita. 2016. Cows, Cars and Cycle-Rickshaws: Bourgeois Environmentalists and the Battle for Delhi's Streets. In Elite and Everyman: The Cultural Politics of the Indian Middle Classes, ed. Amita Baviskar and Raka Ray, 392-418. London: Routledge.

Biswas, Soutik. 2018. The Myth of the Indian Vegetarian Nation. BBC News, 4 April. https://www.bbc.com/news/world-asia-india-43581122. Accessed 7 February 2019.

Bowles, Allen. 2018. Law During Emergencies: Appaddharma. In Oxford History of Hinduism-Hindu Law: A New History of Dharmaśästra, ed. Patrick Olivelle and Donald R. Davis, Jr. Oxford: Oxford University Press.

Carlson, Laurie Winn. 2002. Cattle: An Informal Social History. Chicago: Ivan R. Dee Publisher.

Chakravarti, A.K. 1985. Cattle Development Problems and Programs in India: A Regional Analysis. GeoJournal 10 (1): 21-45.

Dalmiya, Vrinda. 2016. Caring to Know: Comparative Care Ethics, Feminist Epistemology, and the Mahābhārata. New Delhi: Oxford University Press.

Dasa, Syamasundara, and Stuart Coyle. 1998. Protecting Cows: A Handbook of the Principles \& Practices of Vegetarian Cow Husbandry. Hove, Sussex, UK: HATAGRA. 
Dattaśaran̄anand, S. Samivat 2073/2017. Kāmadhenu Kṛpā Prasād (The Merciful Blessings of the Wish-Fulfilling Cow). Pathmedā, Rajasthan, India: Shri Kamdhenu Prakashan Samiti.

Dhama, K., R.S. Chauhan, and L. Singhal. 2005. Anti-Cancer Activity of Cow Urine: Current Status and Future Directions. International Journal of Cow Science 1 (2): 1-25.

Dorman, Eric R. 2011. Hinduism and Science: The State of the South Asian Science and Religion Discourse. Zygon 46 (3): 593-619.

Doron, A., and R. Jeffrey. 2018. Waste of a Nation: Garbage and Growth in India. Cambridge, MA: Harvard University Press.

Gadgil, Madhav, and Ramachandra Guha. 1995. Ecology and Equity: The Use and Abuse of Nature in Contemporary India. London: Routledge.

Gandhi, Mohandas K. 1999. The Collected Works of Mahatma Gandhi (CWMG). New Delhi: Publications Division Government of India.

Gandhiok, Jasjeev. 2019. Gaushalas Haven't Got Promised Delhi Government, Corporation Funds for a Year. Times of India, 16 January. https:// timesofindia.indiatimes.com/city/delhi/gaushalas-havent-got-promiseddelhi-government-corporation-funds-for-a-year/articleshow/67548865.cms? fbclid $=\mathrm{Iw} \% \mathrm{E} 2 \% 80 \% A 6$. Accessed 12 February 2019.

Ganguli, Kisari Mohan, trans. 1991 [1970]. The Mahabharata of KrishnaDwaipayana Vyasa. New Delhi: Motilal Banarsidass.

Goswami, H.D. 2015. A Comprehensive Guide to Bhagavad-Gìtā with Literal Translation. Gainesville, FL: Krishna West.

Henry, Paget. 2015. Indigenous Knowledge: An Engagement with George Sefa Dei. Confluence: Online Journal of World Philosophies 2. https://scholarworks. iu.edu/iupjournals/index.php/confluence/issue/view/26.

Holdrege, Barbara A. 2015. Bhakti and Embodiment: Fashioning Divine Bodies and Devotional Bodies in Krșna Bhakti. London: Routledge.

Human Development Report. 2004. Punjab. Government of Punjab.

IIT Delhi Students Fight Air Pollution By Replacing Wood With Cow Dung Logs For Cremating Dead, 21 October 2018. https:// amp.indiatimes.com/news/india/iit-delhi-students-fight-air-pollutionby-replacing-wood-with-cow-dung-logs-for-cremating-dead-355168. html?fbclid=IwAR0GWQRsPvdQE_bE5HPpmJKl43cM9EDhsC1Siajw2hHxxliW0AES_AmI5M. Accessed 6 December 2018.

Jacob, Ludwig M. 2014. Dr. Jacobs Weg des genussvollen Verzichts: Die effektivsten Maßnahmen zur Prävention und Therapie von Zivilisationskrankeiten. Heidesheim am Rhein: NutricaMEDia. 
Jain, Pankaj. 2011. Dharma and Ecology of Hindu Communities: Sustenance and Sustainability. Farnham, UK: Ashgate.

Jain, N.P., V.B. Gupta, R. Garg, N. Silawat. 2010. Efficacy of Cow Urine Therapy on Various Cancer Patients in Mandsaur District, India-A Survey. International Journal of Green Pharmacy (January-March). https://doi.org/10.4103/ 0973-8251.62163.

Jha, Shiv Pujan. 2017. Uttar Pradesh: Here's Why People Abandon Cows in Bundelkhand. https://www.indiatoday.in/india/story/abandoned-cowsbundelkhand-anna-pratha-vigilante-groups-972987-2017-04-22\#closeoverlay. Accessed 30 November 2018.

Johnson, Lisa. 2012. Power, Knowledge, Animals. New York: Palgrave Macmillan. Kennedy, Uttara, Arvind Sharma, and Clive J. C. Phillips. 2018. The Sheltering of Unwanted Cattle, Experiences in India and Implications for Cattle Industries Elsewhere. Animals 8(64). https://doi.org/10.3390/ani8050064.

Khanna, Sujoy Dr., Maneka Sanjay Gandhi, and Meenakshi Awasthi. 2017. Gaushala. New Delhi: People for Animals.

Khare, R.S. (ed.). 1992. The Eternal Food: Gastronomic Ideas and Experience of Hindus and Buddhists. Albany, NY: State University of New York Press.

Lodrick, Deryck O. 1981. Sacred Cows, Sacred Places: Origins and Survivals of Animal Homes in India. Berkeley: University of California Press.

Mahias, Marie-Claude. 1987. Milk and Its Transmutations in Indian Society. Food and Foodways 2 (1): 265-288. https://doi.org/10.1080/07409710.1987. 9961921.

'Maithilah' Paṇita Gañgādharapāthakah. Vikram S. 2068/2011. Gavārcanaprayogah-Sațīka-tippan̄i-vibhūsita-gosambandhi-vividhānușthānasamanvitah. Pathmeḍa, Rajasthan: Śrī Kāmadhenu Prakāśana Samitị.

Malakoff, Peter. 2005. Ghee: A Short Consideration from an Ayurvedic Perspective. http://www.ancientorganics.com/ghee-a-short-consideration-froman-ayurvedic-perspective/. Accessed 8 June 2019.

Marshall, Michael. 2019. Why Humans Have Evolved to Drink Milk. http:// www.bbc.com/future/story/20190218-when-did-humans-start-drinkingcows-milk. Accessed 21 February 2019.

Mohanty, Ipsita, M.R. Senapati, D. Jena, and S. Palai. 2014. Diversified Uses of Cow Urine. International Journal of Pharmacy and Pharmaceutical Sciences 6 (3): 20-22.

NA. n.d. Cow Protection—Book 1. Moundsville, WV: ISKCON Ministry of Cow Protection and Agriculture.

NA. n.d. Guidelines on Animal Traction. Pretoria: Directorate, Animal and Aquaculture Production. 
NA. n.d. Kāmadhenu Krṣi Tantra Kisān Praśikșaṇ Sibir Pustikā (Kamadhenu Farming Techniques Farmer Training Camp Pamphlet). Nagpur, India: Go Vigyan Anusandhan Kendra.

NA. n.d. Research Activity Book. Nagpur, India: Go Vigyan Anusandhan Kendra \& Gorakshan Sabha.

Nagy, Kelsi. 2019. The Sacred and Mundane Cow: The History of India’s Cattle Protection Movement. In The Routledge Handbook of Religion and Animal Ethics, ed. Andrew Linzey and Clair Linzey. London: Routledge.

Narayanan, Yamini. 2017. Cow Protectionism and Indian Animal Advocacy: The Fracturing and Fusing of Social Movements, 14 July 2017. https://archive.org/ details/YaminiN. Accessed 6 December 2018.

Padmanabhan, Seetha, and V. Varadachari (eds.). 1982. Padma Samihitā. Chennai: Pancaratra Parisodhana Parisad.

Pallavi, Aparna. 2015. The Deshi Cow Milk Jinx. Down to Earth, 7 June 2015. https://www.downtoearth.org.in/blog/the-deshi-cow-milk-jinx45095. Accessed 17 February 2019.

Prabhupāda, A.C. Bhaktivedanta Swami. 2005. Śrī Caitanya-Caritāmrtta of Krṣnadāsa Kavirāja Gosvāmī (One Volume Edition). Los Angeles: Bhaktivedanta Book Trust.

Prabhupāda, A.C. Bhaktivedanta Swami. 2017. The Complete Teachings of His Divine Grace A. C. Bhaktivedanta Swami Prabhupāda. Vedabase CD-ROM Version 2017.2. Sandy Ridge, NC: Bhaktivedanta Archives.

Rangarajan, L.N. (ed.). 1992. Kautilya: The Arthashastra. New Delhi: Penguin. Rastogi, Sanjeev, and Krishna Kaphle. 2011. Sustainable Traditional Medicine: Taking the Inspirations from Ancient Veterinary Science. Evidence-Based Complementary and Alternative Medicine. http://dx.doi.org/10.1093/ecam/ nen071.

Roy, Tirthankar. 2017. Land Quality, Carrying Capacity and Sustainable Agricultural Change in Twentieth-Century India. In Economic Development and Environmental History in the Anthropocene: Perspectives on Asia and Africa, 159-178. London: Bloomsbury Academic.

Satyanarayana, T., B.N. Johri, and A. Prakash (eds.). 2012. Microorganisms in Sustainable Agriculture and Biotechnology. Dordrecht: Springer.

Schmidt, Ron. 2009. The Untold Story of Milk. Revised ed. Washington, DC: New Trends Publishing.

Scholten, Bruce A. 2010. Operation Flood, Food Aid, and Development. London: I.B. Tauris.

Sharma, B.V.V.S.R. 1980. The Study of Cow in Sanskrit Literature. Delhi: GDK Publications. 
Shiva, Vandana. 2016. Who Really Feeds the World? The Failures of Agribusiness and the Promise of Agroecology. Berkeley, CA: North Atlantic Books.

Simoons, Frederick J. 1974. The Purificatory Role of the Five Products of the Cow in Hinduism. Ecology of Food and Nutrition 3(1), 21-34. http://dx.doi. org/10.1080/03670244.1974.9990358. Accessed 8 August 2017.

Sinha, S.N. (ed.). 2016. Cow Keeping in India. 5th ed. (1st ed. 1891, I.S.A. Tweed). New Delhi: Biotech Books.

Smil, Vaclav. 2013. Should We Eat Meat? Evolution and Consequences of Modern Carnivory. Oxford: Wiley-Blackwell.

Smith, David. 2003. Hinduism and Modernity. Oxford: Blackwell.

Somvanshi, R. 2006. Veterinary Medicine and Animal Keeping in Ancient India. Asian Agri-History 10 (2): 133-146.

Sun Jianxin, Xu, Xia Lu Leiming, Gregory W. Yelland, Jiayi Ni, and Andrew J. Clarke. 2016. Effects of Milk Containing Only A2 Beta Casein Versus Milk Containing Both A1 and A2 Beta Casein Proteins on Gastrointestinal Physiology, Symptoms of Discomfort, and Cognitive Behavior of People with Self-Reported Intolerance to Traditional Cows' Milk. Nutrition Journal 15: 35. https://doi.org/10.1186/s12937-016-0147-z.

Taking Pain Out of Cattle Castration is Among Animal Welfare Reforms Now Required in India. n.d. https:/www.petaindia.com/media/taking-pain-cattlecastration-among-animal-welfare-reforms-now-required-india/. Accessed 29 November 2018.

Tiwari, Lalit. n.d. Animal Husbandry and Cattle Management in Arthashastra. http://www.indianscience.org/essays/t_es_arthasastra_husbandry.shtml. Accessed 24 August 2017.

Toomey, Paul M. 1994. Food from the Mouth of Krishna: Feasts and Festivals in a North Indian Pilgrimage Centre. Delhi: Hindustan Publishing Corporation.

Turnbull, Jonathan. 2017. Got Milk? Material Biopolitics and More-ThanHuman Health at the Gaushala. Unpublished MSc. dissertation, University of Oxford.

Valpey, Kenneth. 2010. Pūjā and Darśana. In The Brill Encyclopedia of Hinduism, vol. 2. Amsterdam: Brill.

Velten, Hannah. 2010. Milk: A Global History. London: Reaktion Books.

World Animal Protection. 2014. A Case Study of High Welfare Milk Production in India. https://www.worldanimalprotection.org.in/sites/default/ files/in_files/high-welfare-milk-production-india.pdf. Accessed 23 November 2018. 
Open Access This chapter is licensed under the terms of the Creative Commons Attribution 4.0 International License (http://creativecommons.org/licenses/by/ $4.0 /$ ), which permits use, sharing, adaptation, distribution and reproduction in any medium or format, as long as you give appropriate credit to the original author(s) and the source, provide a link to the Creative Commons license and indicate if changes were made.

The images or other third party material in this chapter are included in the chapter's Creative Commons license, unless indicated otherwise in a credit line to the material. If material is not included in the chapter's Creative Commons license and your intended use is not permitted by statutory regulation or exceeds the permitted use, you will need to obtain permission directly from the copyright holder.

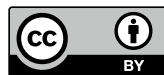

